Article

\title{
Reliability of Creative Composite Indicators with Territorial Specification in the EU
}

\author{
Iván Boal-San Miguel *(1) and Luis César Herrero-Prieto $(1)$
}

Research Group on Cultural Economics and Department of Applied Economics, Faculty of Commerce, University of Valladolid, 47011 Valladolid, Spain; herrero@emp.uva.es

* Correspondence: ivan.boal@uva.es

Received: 10 March 2020; Accepted: 9 April 2020; Published: 11 April 2020

\begin{abstract}
There is wide consensus regarding the capacity of the creative economy as a factor in economic development and sustainability in regions in the medium term, and it is an issue that has aroused interest in measuring the creative potential of areas by estimating composite indicators. Most works posit indicators by countries or cities and normally employ a single aggregation method. This work proposes the construction of a synthetic indicator of creativity with regional disaggregation for a wide sample of European countries, comparing different aggregation methods under the hypothesis of the benefit of the doubt $(\mathrm{BoD})$. We use Eurostat data and also analyse spatial dependence processes. Findings point to an inequality in the regional distribution of creativity in Europe and this reveals creative gap models in areas, suggesting that creativity triggers greater spatial disparities wherever it is found. The principal creative clusters are located in regions in central and northern Europe, particularly in regions with national capitals. The regional distribution of the indicator evidences positive spatial dependence, thereby revealing the existence of spatial externalities that provide feedback for the concentration process and, therefore, a widening of the disparities.
\end{abstract}

Keywords: creativity; European regions; composite indicators; creative cluster; distance measures; data envelopment analysis; principal component analysis; spatial analysis

\section{Introduction}

By creativity, we understand a process of formulating new ideas and applying them to produce original works of art and cultural products, functional creations, scientific inventions and technological innovations as well as their conversion into market goods and services [1]. Thus defined, they would seem to have made a substantial contribution in recent times to economic and urban development and now provide a new area of competitiveness for territories. An excellent review of what contribution creativity makes to the economy may be found in the works of Correa-Quezada et al. [2] and Rodrigues and Franco [3]. Creative potential has also triggered a new competitiveness profile for regions and cities. In this regard, see the delimitation of the concept of creative cities provided by Scott [4] and the new definition of competitive advantages for regions in Sleuwaegen and Ramboer [5]. In the academic sphere, there are two main approaches to measuring the scale of the creative economy: the sectorial or the occupational perspective. The former was the first to appear and focuses on identifying creative industries in a given area. It has yielded abundant literature to define the sector, with more or less widespread agreement concerning the UNCTAD catalogue of branches [1]. This approach has also led to a number of studies aimed at measuring the sector's dimension and the territorial impact of the creative industry, with numerous applied exercises, many of which may be found for the European Union $[5,6]$ as well as for the rest of the world [7-9]. The latter, which appeared later, and which is the so-called occupational approach, is essentially based on Richard Florida's work [10] addressing the concept of the creative class, a group of professionals dedicated to activities related to more stylised cultural creation 
but that also embraces all of those specialising in designing and forging creative activities geared towards the market and that display a certain level of talent and skill and who tend to concentrate in specific areas that exhibit certain conditions and lifestyles [11]. There is also the stream that has given rise to numerous studies aimed at measuring the scale of the territorial agglomeration of creative classes, which is generally measured through the employment variable in creative occupations $[2,12,13]$. Based on the two approaches, many works have appeared that strive to develop a theoretical framework explaining the link between creativity and economic development $[14,15]$ and to show how creativity can shape an area's competitive advantage $[5,16]$, and which also provide ample margin to design and implement new regional policies [3,17]. In general terms, there is consensus vis-à-vis accepting the accumulation of human capital, the capacity for innovation and the current state of technology as drivers that encourage the development of creative industries and/or classes, coupled with conditions of tolerance and openness towards society, as originally posited in the works of Florida [10] but which has also been shown in other more recent studies such as Boschma and Fritsch [12] and Sleugwaegen and Ramboer [5]. One aspect which is being seen as increasingly important is the pre-existence of cultural amenities and an intense level of cultural characterisation in the area in question as highlighted in the works of Cerisola [14] and Backman and Nilsson [18]. The spatial dimension thus proves fundamental in creative sectors and is the context in which cooperation networks are also present that enable knowledge to be disseminated and creative processes to be generated, as pointed out by Rodrigues and Franco [3]. The creation of networks and alliances that are characteristic of the organisational models of creative activities, and the retention of talent, are strongly influenced by the local context [19], which impacts the capacity to create synergies between creative classes who seek to benefit from economies of agglomeration. In this way, European regional policy highlights the creative sector as being key towards fostering intelligent, sustainable and integrating growth, where creativity plays a vital role in regional policy strategy $[13,20]$.

The implications creativity has for economic development and the sustainability of regions requires constant diagnosis and assessment, which can then aid decision making and help to gauge the effectiveness of regional policies. This is the main motivation underlying our research, wherein we aim to build an indicator of creative potential at a disaggregated territorial scale for a broad sample of countries and regions in an effort to show operational utility in current understanding of territorial disparities and what the implications might be for regional policy. Nevertheless, measuring creativity with territorial scope proves complex, given the difficulty in defining and delimiting the area of culture and the various components that make up creativity, as pointed out by Ortega-Villa and Ley-García [21], Kemeny et al. [13] and Rodrigues and Franco [22], and because of the myriad of aspects involved and the enormous heterogeneity of the actors concerned. In addition, data that are appropriate, sufficient and comparable between the various demarcations are required if effective measurements of territorial creative potential are to be carried out. Although the last ten years have witnessed a proliferation of studies involving composite creativity indicators [3,23,24], there remains a lack of studies which at the same time consider a wide sample of countries and significant territorial disaggregation at a regional scale. Moreover, few indices extensively embrace primary indicators of cultural activity (endowment and participation), which are shown to be a key basis of creativity $[21,25]$.

Based on these premises, the present work specifically aims to construct a composite indicator for creativity with a specification for European regions and which we term the European Indicator of Regional Creativity (EIRC). To achieve this, and after considering several dimensions of creativity based on a wide sample of primary variables related to these dimensions, we compare various statistical aggregation methods that determine the importance of each underlying component of creativity, which allows us to examine the robustness and reliability of the indicator estimated. In addition, we aim to identify spatial patterns of creativity in European regions and to estimate the effects of spatial autocorrelation in an effort to verify the existence of economies of agglomeration and creative clusters. We therefore define creative clusters based on spatial interaction processes between territories, considering significant dependence relations of the creativity indicator, along the line of the works by 
Bertacchini and Borrione [26] and He and Gebhardt [9]. The empirical application is carried out on a wide sample of EU countries for which we have been able to compile a reasonable and homogeneous number of variables that are representative of creativity at the NUTS2 regional level. Considerable effort has also been made to compile different Eurostat databases so as to include primary variables from the cultural and creative sector. The technique involves applying three aggregation methods based on the principle of the benefit of the doubt $(\mathrm{BoD})$. This allows us to select the weights inside the data: Principal Component Analysis (PCA), Data Envelopment Analysis (DEA) and Measure of Distance $\mathrm{P}_{2}$ (DP2). Descriptive techniques based on Geographical Information System (GIS mapping) are used for territorial analysis, and spatial econometric tools are applied to spatial dependence phenomena and territorial clusters.

In sum, the principal contributions our study makes in relation to the comparative literature on the matter are mainly grounded on the construction of an indicator of creative potential with regional specification for a broad sample of European countries, whereas studies thus far have tended to be conducted at a country level or to take smaller regional samples. A relative comparison of what this effort has meant vis-à-vis the work carried out to date may be seen in the review of creativity indicators provided in the following section. We also evidence the reliability of composite indicators by applying different aggregation methods based on endogenous weights. This is an important methodological issue when building composite indicators given that, depending on the aggregation method applied, the final indicator might prove to be totally different. In this regard, in contrast to methods based on discretional interventions with previously established or agreed weightings [25], we opted for aggregation criteria where the weightings stem from the actual underlying structure of the data $(\mathrm{BoD}$ criteria) since we believe that an indicator built in this way provides a better reflection of the reality explained. Finally, as regards the results, we evidence a new source of regional disparities since we demonstrate that creativity behaves along the lines of technology gap models, creating greater spatial imbalances wherever these are most apparent. We also determined creative clusters after analysing spatial dependence on creativity indicator results. The work is, therefore, eminently instrumental and empirical and seeks to extend current knowledge concerning how to measure creative potential at a territorial level and to ascertain the spatial logic which is specifically evident at a European scale. All of these results prove useful to both the scientific community and policymakers alike.

Based on the above, the work is structured in five sections. In addition to this introduction, Section 2 deals with the conceptual framework of creativity and provides a review of the literature on composite indicators of culture and creativity and the analysis of underlying dimensions. Section 3 addresses the data and the sources used in the work, together with the methodological stages involved in constructing the indicator and the various aggregation methods employed. Section 4 then presents the empirical application, with the results of the composite indicators for creativity and their spatial distribution in European regions, as well as spatial dependence analysis. The work finishes with the conclusions section.

\section{Review of the Literature on Indicators and Components of Creativity}

Creativity is a complex and multidimensional phenomenon [22] involving multiple components (skills, talent, cultural support, innovative capacity, etc.), which makes measuring it difficult. There is no single definition for this term and creativity is studied from disciplines as far and wide as psychology, the arts and sociology and is a concept that is subject to a myriad of interpretations [27]. Yet when speaking of the creative economy, we are assuming that the end result of the innovation process gives rise to ideas or results that have economic implications, which may be subject to valuation in the market [1]. When generating these creative processes, the importance of the social and territorial factor should be highlighted, since creativity stems from the interaction between these components over a given area, with the role played by spatial demarcations proving particularly crucial in the geography of creativity. The existence of a favourable environment coupled with the driving forces behind creative processes can provide a given region with greater competitive advantage compared 
to others [22], and it can also generate a virtuous circle because the creative classes in turn demand creative goods and services and tend to concentrate where these are to be found [12]. As pointed out by Cerisola [14], only when there is cross fertilization of different types of talent does creativity give rise to sustained local economic development processes, such that creativity should be approached from three perspectives: artistic (a cultural background of the environment), technological (capacity to innovate and the current state of technology) and economic (a capacity for entrepreneurship and the ability to create new products).

Even though efforts to gather and analyse cultural indicators are by no means new [21,28], there have been a number of works in recent years focusing particularly on constructing creativity and cultural activity indices, in an attempt to evidence what contribution these factors make to the economic development and sustainability of regions, as is shown, for example, through the works of Correa-Quezada et al. [2] for the case of Ecuador, and Sleuwaegen and Ramboer [5] for Europe. This line of work has also been boosted by the standardisation and proliferation of cultural statistics both at an international [29] as well as a European [30] level. In an effort to be as thorough as possible, Table 1 provides an overview of the principal composite indicators for the creative economy together with the main underlying dimensions included, the case study and the aggregation methods employed. Nevertheless, conceptual models of cultural and creative indicators and compilations of existing indicators may also be consulted in Stano and Weziak-Bialowolska [31], Ortega-Villa and Ley-García [21] and Rodrigues and Franco [22].

Table 1. Overview of composite cultural and creative indicators.

\begin{tabular}{|c|c|c|c|}
\hline Indicators & Dimensions & Application & Weighting Criteria \\
\hline $\begin{array}{l}\text { Florida's Creative } \\
\text { Index [10] }\end{array}$ & Talent, Technology and Tolerance & Metropolitan areas & Equal weights \\
\hline $\begin{array}{l}\text { Silicon Valley's Creative } \\
\text { Community Index [32] }\end{array}$ & $\begin{array}{l}\text { Talent, Openness, Culture, Technology, } \\
\text { Regulation, Employment, Entrepreneurship }\end{array}$ & Silicon Valley & Analysis by dimensions \\
\hline Cultural Life Index [33] & $\begin{array}{l}\text { Cultural resources, Cultural participation } \\
\text { and Cultural production }\end{array}$ & Without application & $\begin{array}{l}\text { Theoretical proposal of } \\
\text { indicators }\end{array}$ \\
\hline Euro-Creativity Index [11] & Talent, Technology and Tolerance & $\begin{array}{l}14 \text { European countries } \\
\text { and US }\end{array}$ & $\begin{array}{l}\text { Sum of the dimension } \\
\text { scores divided by the } \\
\text { maximum possible score }\end{array}$ \\
\hline $\begin{array}{l}\text { Hong Kong Creativity } \\
\text { Index [34] }\end{array}$ & $\begin{array}{l}\text { Social, Human, Cultural, Structural and } \\
\text { Institutional Capital }\end{array}$ & Hong Kong & Multivariate analysis \\
\hline $\begin{array}{l}\text { Composite Index of the } \\
\text { Creative Economy [35] }\end{array}$ & $\begin{array}{l}\text { Innovation, Entrepreneurship and } \\
\text { Openness }\end{array}$ & Nine regions & $\begin{array}{l}\text { Endogenous } \\
\text { weighting-DEA }\end{array}$ \\
\hline $\begin{array}{l}\text { European Creativity } \\
\text { Index [36] }\end{array}$ & $\begin{array}{l}\text { Human capital, Openness and diversity, } \\
\text { Cultural environment, Technology, } \\
\text { Institutional environment, Creative outputs }\end{array}$ & $\begin{array}{l}\text { European countries, } \\
\text { without empirical } \\
\text { application }\end{array}$ & $\begin{array}{l}\text { Theoretical proposal of } \\
\text { indicators }\end{array}$ \\
\hline $\begin{array}{l}\text { Design, Creativity and } \\
\text { Innovation } \\
\text { Scoreboard [37] }\end{array}$ & $\begin{array}{l}\text { Creative education, Self-expression, } \\
\text { Openness, Creative sector, Creativity in } \\
\text { R\&D, Design activities, Competitiveness in } \\
\text { design }\end{array}$ & European countries & $\begin{array}{l}\text { Equal weights } \\
\text { unweighted average }\end{array}$ \\
\hline Czech Creative Index [38] & Talent, Technology and Tolerance & Czech regions & $\begin{array}{l}\text { Fuzzy method. Weights } \\
\text { depending on the } \\
\text { distance to the best } \\
\text { region's score }\end{array}$ \\
\hline Creative Grid [39] & $\begin{array}{l}\text { Creative class, Culture, Talent, Government, } \\
\text { Creative and Culture industries }\end{array}$ & Proposal for the UK & $\begin{array}{l}\text { Only a proposal of key } \\
\text { themes for the creative } \\
\text { economy }\end{array}$ \\
\hline Creative City Index [40] & $\begin{array}{l}\text { Political frameworks, Diversity, Openness, } \\
\text { Trust, Accessibility, Entrepreneurship. } \\
\text { Innovation, Talent, Connectivity and } \\
\text { networking, Liveability and well-being, } \\
\text { Communication }\end{array}$ & 20 Cities & $\begin{array}{l}\text { External weighting by } \\
\text { experts }\end{array}$ \\
\hline
\end{tabular}


Table 1. Cont.

\begin{tabular}{|c|c|c|c|}
\hline Indicators & Dimensions & Application & Weighting Criteria \\
\hline Creative City Index [41] & $\begin{array}{l}\text { Creative industries, Microproductivity and } \\
\text { microproduction, Economy of attention, } \\
\text { Participation and expenditure, Public } \\
\text { support, Human capital, Global integration, } \\
\text { Openness, Tolerance }\end{array}$ & Six Cities & Equal weights \\
\hline Creative Space Index [23] & $\begin{array}{l}\text { Talent, Openness, Culture and Tourism, } \\
\text { Technology and Innovation, Industry, } \\
\text { Regulation and Incentives, } \\
\text { Entrepreneurship, Accessibility, Liveability }\end{array}$ & 26 European countries & $\begin{array}{l}\text { Endogenous } \\
\text { weighting-DEA }\end{array}$ \\
\hline $\begin{array}{l}\text { Global Creativity } \\
\text { Index [42] }\end{array}$ & Talent, Technology and Tolerance & 139 countries & Equal weights \\
\hline $\begin{array}{l}\text { Creative Economy } \\
\text { Index [43] }\end{array}$ & $\begin{array}{l}\text { Talent, Research systems, Finance and } \\
\text { support, Investments, Entrepreneurship, } \\
\text { Intellectual assets, Innovators, Economic } \\
\text { effects }\end{array}$ & 34 European countries & Multivariate analysis \\
\hline $\begin{array}{l}\text { European } 3 T \text { Creativity } \\
\text { Index [24] }\end{array}$ & $\begin{array}{l}\text { 3T with Creative Class, Human Capital, } \\
\text { Scientific Talent, Innovation, High tech } \\
\text { innovation, R\&D, Attitudes index, Values } \\
\text { index, Self-expression index }\end{array}$ & 28 European countries & Equal weights \\
\hline $\begin{array}{l}\text { Creativity Index for } \\
\text { Portuguese Cities [3] }\end{array}$ & $\begin{array}{l}\text { Places of Culture, Cultural Participation, } \\
\text { Creative Industries, Research \& } \\
\text { Development, Innovation, Human Capital, } \\
\text { Openness, Connections, Governance }\end{array}$ & Portuguese cities & Multivariate analysis \\
\hline $\begin{array}{l}\text { Cultural and Creative } \\
\text { Cities Index [25] }\end{array}$ & $\begin{array}{l}\text { Cultural Vibrancy, Creative Economy, } \\
\text { Human Capital, Openness, Connections } \\
\text { and Quality of governance }\end{array}$ & European Cities & $\begin{array}{l}\text { Budget allocation } \\
\text { method }\end{array}$ \\
\hline
\end{tabular}

Source: Authors' own.

Various creative indicators have been constructed for the European context, although measurement thereof for the regional territorial level and in the context of several countries remains scarce, with the sample of regions included tending to be small. The most recent indicators applied at a country level (Global Creativity Index [42], Creative Space Index [23], Creative Economy Index [43]) have increased the number of latent dimensions and countries. Recent studies into creative indicators have sought to explore the network of cities in a given country (Creativity Index for Portuguese Cities [3]) or for large European cities (Cultural and Creative Cities Index [25]). By estimating the EIRC in our work, we aim to cover one of the more underexplored areas, namely European regional analysis for an ample number of countries, and to compare various aggregation methods based on $\mathrm{BoD}$ principles, which in turn enables us to analyse the reliability and robustness of the results. In doing so, we seek to examine the current situation and trends of European spatial disparities in terms of creative capacity.

Based on the review of the existing composite indicators in the literature (Table 1) and subject to the availability of data for the regional level considered in this work, we identify six operational dimensions underlying the creative economy and which constitute the reference for compiling primary variables for comparing and constructing partial indicators for each dimension. As a result, we are not actually defining creativity itself but are rather exploring and explaining which components feed said concept, based on tested processes related to the accumulation of talent, the degree of openness and the innovative capacity of the environment and which we have furthered by taking into account a broad sample of variables that are representative of cultural participation and of the creative industry, conscious of the fact that these are key to creativity [21]. These dimensions are shown in Figure 1 and are described in detail below, whilst the primary variables that make up each dimension are displayed in Table 2. 
Table 2. Dimensions, indicators, variables and descriptive statistics of the European Indicator of Regional Creativity (EIRC).

\begin{tabular}{|c|c|c|c|c|c|c|c|c|c|}
\hline Dimension & Description of the Variables & Source & $\begin{array}{l}\text { Period of } \\
\text { Reference }\end{array}$ & Obs. & Minimum & Maximum & Mean & SD & Formulae \\
\hline \multirow{3}{*}{ Talent } & TA1: Number of bachelor degrees per capita & Eurostat: Regions & 2015 & 171 & 11.600 & 54.100 & 28.918 & 8.285 & \multirow{3}{*}{$\begin{aligned} I_{-} T A_{i} & =\frac{x_{T A_{i}}}{\max \left(x_{T A_{i}}\right)}, \mathrm{i}=1,2,3 \\
P I_{-} T A & =\sqrt[n]{\prod_{i=1}^{n} I_{-} T A_{i}}, \mathrm{n}=3\end{aligned}$} \\
\hline & TA2: Number of people in creative occupations per capita & Eurostat: Regions & 2015 & 171 & 0.008 & 0.105 & 0.037 & 0.016 & \\
\hline & TA3: Number of people in arts occupations per capita & Eurostat: Regions & 2015 & 171 & 0.006 & 0.047 & 0.021 & 0.007 & \\
\hline \multirow{3}{*}{$\begin{array}{l}\text { Openness and } \\
\text { Tolerance }\end{array}$} & \multirow{3}{*}{$\begin{array}{l}\text { OP1: Share of non-nationals among residents } \\
\text { OP2: Share of non-national bachelor degrees among } \\
\text { non-nationals } \\
\text { OP3: Employment rate of foreigners }\end{array}$} & Eurostat: Regions & 2015 & 171 & 0.001 & 0.309 & 0.051 & 0.048 & \multirow{3}{*}{$\begin{aligned} I_{-} O P_{i} & =\frac{x_{O P_{i}}}{\max \left(x_{O P_{i}}\right)}, \mathrm{i}=1,2,3 \\
P I \_O P & =\sqrt[n]{\prod_{i=1}^{n} I_{-} O P_{i}}, \mathrm{n}=3\end{aligned}$} \\
\hline & & Eurostat: Regions & 2011 & 171 & 0.107 & 4.810 & 0.603 & 0.593 & \\
\hline & & Eurostat: Regions & 2011 & 171 & 38.900 & 84.600 & 62.106 & 8.719 & \\
\hline \multirow{5}{*}{ Culture } & CU1: Number of cinema seats per capita & Eurostat: Cities & 2015 & 171 & 228.085 & $18,500.359$ & $5,489.519$ & $3,506.160$ & \multirow{5}{*}{$\begin{array}{l}I_{-} C U_{i}=\frac{x_{C U_{i}}}{\max \left(x_{C U_{i}}\right)}, \mathrm{i}=1,2,3,4,5 \\
P I_{-} C U=\sqrt[n]{\prod_{i=1}^{n} I_{-} C U_{i}}, \mathrm{n}=5\end{array}$} \\
\hline & CU2: Number of theatres per capita & Eurostat: Cities & 2015 & 171 & 0.000 & 87.830 & 8.879 & 11.191 & \\
\hline & CU3: Number of public libraries per capita & Eurostat: Cities & 2015 & 171 & 1.486 & 156.515 & 32.141 & 28.762 & \\
\hline & CU4: Cinema attendance per capita & Eurostat: Cities & 2015 & 171 & 0.003 & 4.528 & 0.975 & 0.694 & \\
\hline & CU5: Number of museum visitors per capita & Eurostat: Cities & 2015 & 171 & 0.013 & 4.670 & 0.596 & 0.649 & \\
\hline \multirow{5}{*}{$\begin{array}{l}\text { Technology and } \\
\text { Innovation }\end{array}$} & TE1: R\&D expenditure per capita & Eurostat: Regions & 2015 & 171 & 5.800 & $3,737.300$ & 538.922 & 630.827 & \multirow{5}{*}{$\begin{array}{c}I_{-} T E_{i}=\frac{x_{T E_{i}}}{\max \left(x_{T E_{i}}\right)}, \mathrm{i}=1,2,3,4,5 \\
\text { PI_TE }=\sqrt[n]{\prod_{i=1}^{n} I_{-} T E_{i}}, \mathrm{n}=5\end{array}$} \\
\hline & TE2: Share of R\&D personnel and researchers & Eurostat: Regions & 2015 & 171 & 0.099 & 4.304 & 1.117 & 0.814 & \\
\hline & TE3: Number of patents registered per million inhabitants & Eurostat: Regions & 2012 & 171 & 0.233 & 468.132 & 90.432 & 109.277 & \\
\hline & TE4: Percentage of human resources in science and technology & Eurostat: Regions & 2015 & 171 & 11.800 & 53.700 & 31.468 & 7.720 & \\
\hline & TE5: European Union trademarks per million inhabitants & Eurostat: Regions & 2015 & 171 & 3.969 & 610.396 & 140.430 & 118.461 & \\
\hline \multirow{4}{*}{$\begin{array}{l}\text { Cultural and } \\
\text { Creative } \\
\text { Industries }\end{array}$} & CR1: Number of creative enterprises per capita & Eurostat: Regions & 2015 & 171 & 0.001 & 0.090 & 0.017 & 0.013 & \multirow{4}{*}{$\begin{array}{l}I_{-} C R_{i}=\frac{x_{C R_{i}}}{\max \left(x_{C R_{i}}\right)}, \mathrm{i}=1,2,3,4 \\
P I_{-} C R=\sqrt[n]{\prod_{i=1}^{n} I_{-} C R_{i}}, \mathrm{n}=4\end{array}$} \\
\hline & CR2: Share of employment in creative industries & Eurostat: Regions & 2015 & 171 & 0.002 & 0.179 & 0.077 & 0.027 & \\
\hline & $\begin{array}{l}\text { CR3: Gross fixed capital formation of the creative industries } \\
\text { per million inhabitants }\end{array}$ & Eurostat: Regions & 2015 & 171 & 19.866 & $5,559.190$ & 859.489 & 899.914 & \\
\hline & CR4: Gross value added at basic prices & Eurostat: Regions & 2015 & 171 & 53.667 & $2,249.637$ & 747.132 & 490.857 & \\
\hline \multirow{5}{*}{ Liveability } & LI1: Household income per capita & Eurostat: Regions & 2015 & 171 & $2,100.000$ & $34,100.000$ & $16,491.81$ & $8,534.376$ & \multirow{5}{*}{$\begin{array}{c}I_{-} L I_{i}=\frac{x_{L_{i}}}{\max \left(x_{L_{i}}\right)}, \mathrm{i}=1,2,3,4,5 \\
P I \_L I=\sqrt[n]{\prod_{i=1}^{n} I_{-} L I_{i}}, \mathrm{n}=5\end{array}$} \\
\hline & LI2: Employment rate & Eurostat: Regions & 2015 & 171 & 48.800 & 81.800 & 66.329 & 6.961 & \\
\hline & LI3: Number of years of life expectancy & Eurostat: Regions & 2015 & 171 & 73.500 & 84.500 & 79.936 & 2.665 & \\
\hline & LI4: Available rent per capita & Eurostat: Regions & 2015 & 171 & $2,610.790$ & $26,065.78$ & $14,596.67$ & $6,751.579$ & \\
\hline & $\begin{array}{l}\text { LI5: Percentage of the young population from } 5 \text { to } 34 \text { years } \\
\text { over the total population }\end{array}$ & Eurostat: Regions & 2015 & 171 & 0.260 & 0.415 & 0.343 & 0.030 & \\
\hline
\end{tabular}

Source: authors' own based on Eurostat. 


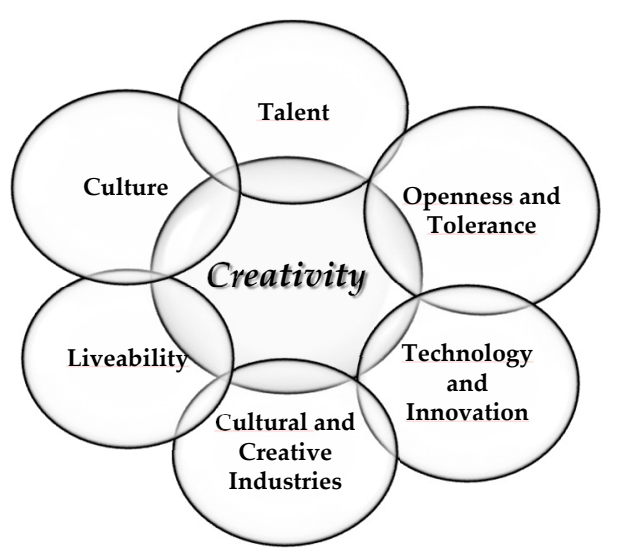

Figure 1. Creative economy dimensions. Source: Authors' own.

1. Talent (TA): we understand talent, on the one hand, to be the accumulation and level of human capital, which constitutes a widely recognised factor as a determinant of economic development and the capacity to innovate [44,45]. Yet also, and specifically, we see it as the degree of concentration of those engaged in artistic and creative activities and that therefore determine the scale of the regional creative sector and its dynamism in the medium term, given the possibility of generating economies of agglomeration and attracting creative classes [10]. It is worth highlighting that a creative environment is characterised by being able to nourish, foster, promote, attract and retain talent [40]. In this dimension, we therefore include basic variables of human capital together with others that are indicative of the number of people employed in creative and artistic jobs in the regions.

2. Openness and Tolerance (OP): social diversity and the exchange of ideas are deemed to be a source of innovation and play a key role in generating creative environments [46]. A tolerant atmosphere and one that is open to diversity is able to attract people of different cultures as well as overseas talent and can enhance an area's creative potential [47]. According to Florida [10] the nucleus of people who make up the so-called creative class tend to settle and concentrate in places that offer an atmosphere of diversity, authenticity or tolerance that is in accordance with their lifestyle. In this dimension, we therefore include variables related to the degree of foreign diversity of a region's population, overseas talent and the capacity to integrate this into the labour market.

3. Culture (CU): a region's cultural capital is made up of the set of tangible and intangible elements that are the expression of ingenuity, history or identity [48]. There is a positive relation between the cultural environment and academic performance [49], such that it also acts as a factor which attracts talent and generates human capital $[18,50]$. In addition, the cultural stock and synergies between the various talents in a region foster creativity and innovative processes, thereby boosting local economic development $[14,51]$. Few creativity indicators cover the dimensions that are most specifically related to the cultural environment [25], probably due to the statistical difficulties involved in compiling data. In this regard, and as we said above, we have striven to gather variables concerning cultural endowment and participation with regional disaggregation, which constitutes one of the principal novelties of this work.

4. Technology and Innovation (TE): research and an area's level of technological development shape its capacity to innovate and generate creative processes, as well as their dissemination in society [22]. The ability to turn technological and innovative effort into economic results is also a factor of territorial competitiveness [9]. In this way, we consider the scope of the R\&D sector in terms of spending and employment as well as the capacity for innovation measured in the number of patents and creation of trade marks to be the representative variables of this dimension, as is also used in Porter et al. [27].

5. Cultural and Creative Industries (CCI): formed by industries that use culture as a resource, although the outputs may be functional and target mass consumption, embracing creative and innovative 
elements in wider-ranging processes. They are aimed at producing and commercialising goods and services with a high degree of cultural, artistic or heritage content and which enable creativity to be expressed, materialised and spread. They display positive externalities, since firms who have production links with this sector are able to include a higher level of innovation in their products [52]. In order to reflect the scale of this sector in European regions, in this dimension we include variables concerning the number of firms, employment, gross aggregate value and gross formation of capital in the cultural and creative sector.

6. Liveability (LI): this notion focuses on the quality of life and wellbeing a given place offers for living, which encourage the location and generation of talent and creative processes. It is one of the dimensions included in the most recent works dealing with creativity indicators [46] and follows the line of OECD wellbeing indicators [53]. Here are included variables addressing job opportunities and level of rent, youth index and population life expectancy.

As mentioned above, the variables finally chosen, and which are representative of each dimension, are shown in attached Table 2, where the source and reference year, in addition to descriptive statistics, are also indicated.

\section{Methodological Approach and Case Study}

\subsection{Constructing Composite Indicators}

Given that creativity is a multidimensional phenomenon, estimating composite indicators allows us to measure regional creative potential based on a synthetic measure that merges the different underlying dimensions. Composite indicators are a mathematical combination of partial indicators that represent the different profiles of a concept being measured [54] and constitute an extremely useful analytical tool for evaluating notions in comparative terms through space and time. One of the most hotly debated issues involves determining which aggregation method to use and which enables the information from the partial indicators to be integrated and summed up [55]. This therefore requires specifying how the weights will be assigned to the original variables, which may ultimately determine the reliability of the outcomes [22,56]. Our methodological approach thus follows two stages. First, we compile the greatest number of primary variables that are representative of each of the underlying dimensions of creativity (See Table 2), and we construct the partial indicators that are representative of each of them. To do this, we employ the method widely recognised and used when constructing the Human Development Index-HDI [57] and which consists of aggregating the variables through multiplicative weighting by geometric mean, thus avoiding the assumption of total compensation [54] and allowing the extreme values to be smoothed [58]. Previously, and in order to facilitate comparative analysis between regions, the scale effect of the primary variables has been removed in the form of rates, percentages or calculations in terms of population (per capita), and the initial values have been normalised through the quotient of each region's value and the maximum value of the sample [59]. The method used to obtain the partial indicators of each dimension is also shown in Table 2. Second, we construct the synthetic indicator for regional creativity (EIRC), adding the partial indicators obtained in the previous stage. A wide range of aggregation methods are available [54,55], and in this work we consider methods based on the benefit of the doubt (BoD) approach, and which obtain the weights endogenously to the data. These are used when, a priori, prior weighting schemes of the partial indicators are not known, and they help with objectivity when constructing the synthetic index [60]. In our research, we use three noncompensatory aggregation methods: Principal Component Analysis (PCA), Data Envelopment Analysis (DEA) and Distance P2 (DP2), which will enable us, on the one hand, to compare the different results, and on the other, to gauge the robustness and reliability of our composite indicator. Various advantages, disadvantages as well as the differences of these aggregation methods can be seen in greater detail $[61,62]$.

PCA has been used by numerous authors when constructing social wellbeing indicators $[63,64]$ as well as for indicators of talent and creativity [3]. It is a multivariate technique designed to reduce the 
original size of a set of variables so that the weight of each variable is proportional to the part of its variance explained by the factor associated to it, whilst each factor is weighted by its contribution to the part of the variance explained in the data set [65]. Through PCA, the indicator is obtained as:

$$
\text { EIRC_PCA } A_{j}=\frac{\sum_{i=1}^{r} Z_{r j} \cdot \sqrt{\lambda_{r}}}{\sum_{i=1}^{r} \sqrt{\lambda_{r}}}
$$

where $Z_{r j}$ is the score of the component $r$-th for region $\mathrm{j}$-th and $\lambda_{r}$ the self-value for said component.

For its part, the DEA method is a nonparametric linear programming technique, which is widely used to measure the efficiency of a set of production units based on optimising the production function. When applied to constructing composite indicators, it is an endogenous aggregation method, since it involves maximising the output values (in our case, dimensions of creativity) subject to the restriction of a hypothetical unitary input. Therefore, the weights are given naturally depending on the initial data range. It is becoming increasingly common to find applications of the DEA method for obtaining composite indicators in the literature, for example in the tourist sector [66] and for wellbeing indices [58,67]. Some creativity indicators also use this technique, as is the case in Bowen et al. [35] for a specific sample of nine creative regions, Correia and Costa [23] for all EU member countries and more recently De Jorge-Moreno and De Jorge-Huertas [68], who estimate a creative composite index for European cities with DEA. The indicator is expressed as follows:

$$
\begin{gathered}
\text { EIRC_DEA } A_{j}=\max _{w_{c, i}} \sum_{i=1}^{m} w_{r, i} * y_{r, i} \\
\text { subject to : } \\
\sum_{i=1}^{m} w_{r, i} * y_{j, i} \leq 1 \forall j \in\{1, \ldots n\} \\
w_{r, i} \geq 0 \forall i \epsilon\{1, \ldots m\}
\end{gathered}
$$

where $n$ represents the number of regions, $m$ the number of partial indicators that are representative of creative dimensions, while $y_{r, i}$ represents the value of the partial indicator $i$ in region $r$, with $w_{r, i}$ being the respective weights.

The DP2 distance based method, defined by [69], avoids some of the usual problems encountered when constructing synthetic indicators such as the aggregation of variables expressed in different measurement units, arbitrary and compensatory weighting and information duplicity, and it allows interspatial and intertemporal comparisons to be carried out. It calculates each region's distance from a reference region which achieves the worst values in the partial indicators, such that a higher value of the distance measured indicates a greater level of creative potential. It has been used in works addressing social indicators [62] and economic indicators [70], although there are very few applications to the domain of creative indicators. It is defined as:

$$
\text { EIRC DP2 }=\sum_{i=1}^{\mathrm{n}}\left\{\left(\frac{d_{i}}{\sigma_{i}}\right)\left(1-R_{i, i-1, \ldots, 1}^{2}\right)\right\}
$$

with $R_{1}^{2}=0$; where $d_{i}=d_{i}\left(r^{*}\right)=\left|x_{r i}-x_{* i}\right|$ and the reference base is $X_{*}=\left(x_{* 1}, x_{* 2}, \ldots, x_{* n}\right)$, where $m$ is the number of regions, $n$ is the number of variables, $x_{i j}$ is the value of variable $i$ in region $j, \sigma_{i}$ is the standard deviation of the variable $i, R^{2}{ }_{i, i-1, \ldots, 1}$ is the coefficient of determination in the regression of $X_{i}$ over $X_{i-1}, X_{i-2}, \ldots, X_{1}$. The input order of the partial indicators, which establishes the relative weight of each variable, is determined through a convergence algorithm and only the new information contributed by each partial indicator is retained, thereby avoiding duplicated information.

Having constructed the EIRC using these three methods, we subsequently assess the reliability and variability of the results. In order to test the indicator's internal validity, we calculate two correlation coefficients of nonparametric ranges: the rho Spearman correlation coefficient and Kendall's tau-b correlation coefficient. The former is a nonparametric version of the Pearson correlation coefficient, 
based on the data range, while the latter is a measure of association for variables of ranges which, unlike the previous one, takes ties into account. Both reach values between -1 and 1 .

\subsection{Spatial Analysis}

In order to conduct a more thorough analysis of the EIRC indicator's territorial distribution and to pinpoint more efficiently the effects of spatial interaction, we use Geographical Information System (GIS mapping) and econometric spatial autocorrelation techniques, used in other studies in the area of culture [17,26,71]. Moran's I global statistic [72] allows us to test for the existence of spatial dependence, reflected in the influence that the creative potential in neighbouring regions has on a particular region's creativity. This statistic is defined as:

$$
I=\frac{N}{S_{0}} \frac{\sum_{i j}^{N} w_{i j}\left(x_{i}-\bar{x}\right)\left(x_{j}-\bar{x}\right)}{\sum_{i=1}^{N}\left(x_{i}-\bar{x}\right)^{2}} i \neq j
$$

where $x_{i}$ is the value of the variable in region $i, \bar{x}$ is a simple average of the variable, $w_{i, j}$ are the components of the spatial weights matrix, $N$ is the sample size, and $\mathrm{S}_{0}=\sum_{\mathrm{i}=1}^{\mathrm{n}} \sum_{\mathrm{j}=1}^{\mathrm{n}} \mathrm{w}_{\mathrm{ij}}$. There are various kinds of spatial weight matrices [73]. In this work, we estimate the first order contiguity matrix, this being one of the most widely used in spatial analysis studies [74].

For its part, the $G i^{*}$ statistic [75] allows significant spatial clusters in regions with similar levels of creativity to be identified:

where

$$
G_{i}^{*}=\frac{\sum_{j=1}^{n} w_{i, j} x_{j}-\bar{X} \sum_{j=1}^{n} w_{i, j}}{S \sqrt{\frac{\left[n \sum_{j=1}^{n} w_{i, j}^{2}-\left(\sum_{j=1}^{n} w_{i, j}\right)^{2}\right]}{n-1}}}
$$

$$
\begin{aligned}
& \bar{X}=\frac{\sum_{j=1}^{n} x_{j}}{n} \\
& S=\sqrt{\frac{\sum_{j=1}^{n} x_{j}^{2}}{n}}-(\bar{x})^{2}
\end{aligned}
$$

$n$ is the number of regions, $x_{j}$ is the value of $j$, and $w_{i j}$ is the spatial weights matrix.

\subsection{Compiling a Database for Empirical Application}

The aim of this work is to build composite indicators of creativity with a level of territorial disaggregation, in European regions, taking as a reference the analytical framework of the underlying dimensions of regional creative potential, explained in Section 2. Few attempts have been made to measure the creative economy at a European regional scale, since it is more common to find indicators at a national level or systems that are restricted to cities. The limitations in terms of statistical availability and the difficulty involved in compiling variables with a high degree of territorial disaggregation only further complicate the task. Nevertheless, it is necessary to consider the regional level within the scope of creative indicators, given the key role these territorial demarcations play in European policies geared towards regional development and territorial sustainability. After verifying the availability of primary homogeneous indicators that are representative of each dimension of creativity, our work is based on creating a database with regional disaggregation for a wide sample of European countries. Sources of statistical information come mainly from EUROSTAT. Specifically, we use the "Regions" data source for all the dimensions of creativity, except for the group of indicators reflecting supply and cultural participation (Culture dimension), for which there are insufficient variables with regional disaggregation. In order to overcome this limitation, and in an effort to embrace the cultural dimension in the final composite indicator, we use the "Cities" database, which contains statistics for European cities. This resource provides us with information concerning aspects related to quality of life in cities and offers a selection of locations with a population of over 50,000 inhabitants, such that the sample is fairly extensive and representative of the European urban system. Unfortunately, countries such as Austria, Greece, the Netherlands, Italy, Luxemburg, Malta and Norway do not record cultural 
information in Cities, as a result of which they had to be excluded from the study. Nor were we able to compile sufficient and homogeneous information with regional disaggregation for countries such as Switzerland and the UK for some of the indicators of the Technology and Liveability dimensions. As a guideline for recovering missing data, in the few regions in which this was the case, we assigned the mean value of the regions from the same country weighted by the population. In regions for which there was no information in the reference year, we took the value of the closest year available. In order to build a consistent database at a regional level, the values of the indicators for supply and cultural participation of the cities contained in the database have been ascribed to their corresponding region. This allows us to standardise the final database and to include the cultural dimension in our indicator. Our case study thus comprises a sample of 20 European Union countries, with a NUTS 2 disaggregation level, and includes a total of 171 regions.

\section{Empirical Application}

In this section, we present the empirical application. First, we present the results of the EIRC in each of the three aggregation methods and we analyse the reliability of the shared results. We then address the geographical distribution of the composite indicator in order to pinpoint territorial disparities, the effects of spatial correlation and the map of regional creativity clusters. All of this will subsequently enable us to interpret and discuss the main results and to derive the most important utilities and implications.

\subsection{Ranking of Regions and Reliability of the EIRC}

Taking into account the synthesis methods described in the methodological section, we estimated three composite indices for the 171 regions in our sample, reflecting different weighting systems for the partial indicators, which are representative of the dimensions of creativity. Based on this analysis, we sought to identify to what extent each particular aggregation technique used impacts the indicator's final result. We first calculated the indicator applying the PCA method, (EIRC_PCA), which was able to embrace a large amount of the information from the original indicators $(71 \%$ of the total explained variance) and which shows good statistical significance results ( $\mathrm{KMO}=0.853$; $\mathrm{p}$-value 0.00$)$. We then apply the DEA method, EIRC_DEA, which endogenously determines a set of weights to measure the relative performance of the regions, comparing them to the regions that offer the best practices. Finally, we calculated the composite indicator based on the DP2 method, EIRC_DP2, which calculates how far each region lies from a theoretical reference region.

Table A1 of the Appendix A shows the results of the three composite indicators for all the European regions, while attached Table 3 shows the classification in the ranking of the top 35 regions, ranked by the results of the first method, as well as each region's average position, the mean deviation and the percentage of population the region represents out of the total population of the country to which it belongs. This is done to first demonstrate that the ranges to emerge from the three aggregation methods do not differ too much and second to show that the regions obtaining the best results in the creativity indicators correspond to the major urban nodes in each country, which account for the areas of greatest population and which are mainly home to national capital cities. Such is the case for Stockholm (SE11), the Region of Bruxelles-Capitale (BE10), Copenhagen in Hovedstaden (DK01), Paris en Île de France (FR10), Helsinki-Uusimaa (FI1B), Madrid (ES30), Dublin (IE02), etc. In our work, also appearing in the top positions of the indicator, even though they are areas of greater decentralisation, are the regions in the south and west of Germany, southern Sweden, the area of Brussels and to a more isolated degree the regions of Cataluña and the País Vasco in Spain as well as Rhône-Alpes in France. These results are in line with other recent works such as Montalto et al. [25] and Jorge-Moreno and De Jorge-Huertas [68] who obtain a ranking of European cities in terms of creative capacity, as well as others which apply a similar approach, albeit at different levels of disaggregation, such as the creativity indices built by Correia and Costa [23] and Alexi et al. [24], who also report a high concentration in countries in central and northern Europe. If we compare the result of the rankings, we see that the 
positions obtained according to the EIRC_PCA and EIRC_DP2 indicators are more similar than the positions obtained in the EIRC_DEA indicator, which evidences greater variability compared to the rest, even though the values of the mean deviation are not very high in general.

Table 3. EIRC indicator ranking, top 35.

\begin{tabular}{|c|c|c|c|c|c|c|c|c|}
\hline $\begin{array}{l}\text { Country } \\
\text { Code }\end{array}$ & $\begin{array}{l}\text { Region } \\
\text { Code }\end{array}$ & Region & $\begin{array}{c}\text { RK } \\
\text { EIRC_PCA }\end{array}$ & $\begin{array}{c}\text { RK } \\
\text { EIRC_DEA }\end{array}$ & $\begin{array}{c}\text { RK } \\
\text { EIRC_DP2 }\end{array}$ & $\bar{x}$ & M.D. & $\begin{array}{l}\% \text { of Pop. Out of } \\
\text { the Country Total }\end{array}$ \\
\hline SE & SE11 & Stockholm & 1 & 1 & 1 & 1.00 & 0.00 & 22.50 \\
\hline DK & DK01 & Hovedstaden & 3 & 7 & 6 & 5.33 & 1.56 & 31.24 \\
\hline FR & FR10 & Île de France & 4 & 3 & 3 & 3.33 & 0.44 & 18.18 \\
\hline FI & FI1B & Helsinki-Uusimaa & 7 & 11 & 10 & 9.33 & 1.56 & 29.30 \\
\hline $\mathrm{DE}$ & DE30 & Berlin & 8 & 21 & 7 & 12.00 & 6.00 & 4.27 \\
\hline $\mathrm{BE}$ & BE31 & Prov. Brabant Wallon & 9 & 37 & 12 & 19.33 & 11.78 & 3.51 \\
\hline $\mathrm{CZ}$ & CZ01 & Praha & 10 & 26 & 5 & 13.67 & 8.22 & 11.95 \\
\hline DE & DE11 & Stuttgart & 11 & 9 & 18 & 12.67 & 3.56 & 4.94 \\
\hline $\mathrm{DE}$ & DE71 & Darmstadt & 12 & 16 & 14 & 14.00 & 1.33 & 4.76 \\
\hline $\mathrm{DE}$ & DE12 & Karlsruhe & 17 & 17 & 23 & 19.00 & 2.67 & 3.35 \\
\hline DE & DE25 & Mittelfranken & 18 & 18 & 20 & 18.67 & 0.89 & 2.11 \\
\hline SK & SK01 & Bratislavský kraj & 19 & 46 & 9 & 24.67 & 14.22 & 11.53 \\
\hline DE & DEA2 & Köln & 20 & 33 & 19 & 24.00 & 6.00 & 5.37 \\
\hline $\mathrm{BE}$ & BE24 & Prov. Vlaams-Brabant & 21 & 20 & 26 & 22.33 & 2.44 & 9.92 \\
\hline SE & SE12 & Östra Mellansverige & 22 & 32 & 22 & 25.33 & 4.44 & 16.64 \\
\hline $\mathrm{DE}$ & DE50 & Bremen & 23 & 49 & 17 & 29.67 & 12.89 & 0.82 \\
\hline $\mathrm{DE}$ & DE14 & Tübingen & 24 & 13 & 31 & 22.67 & 6.44 & 2.21 \\
\hline $\mathrm{DE}$ & DEA1 & Düsseldorf & 25 & 45 & 25 & 31.67 & 8.89 & 6.29 \\
\hline $\mathrm{DE}$ & DEB3 & Rheinhessen-Pfalz & 26 & 29 & 34 & 29.67 & 2.89 & 2.48 \\
\hline $\mathrm{DE}$ & DE13 & Freiburg & 27 & 14 & 38 & 26.33 & 8.22 & 2.70 \\
\hline
\end{tabular}

Note: M.D. is the mean deviation between the different ranges obtained by region. Population data are the percentage of population each region represents out of the total for its country, 2015 data. Source: authors' own.

Taking the EIRC_PCA indicator as a reference, Figure 2 shows the dispersion analysis of results for countries through a boxplot analysis. Once again, we see how the main extreme points in the distribution of creative potential correspond to the regions that contain national capitals. These results are also reported by Montalto et al. [25] for a study of the creative potential in the main European cities. 


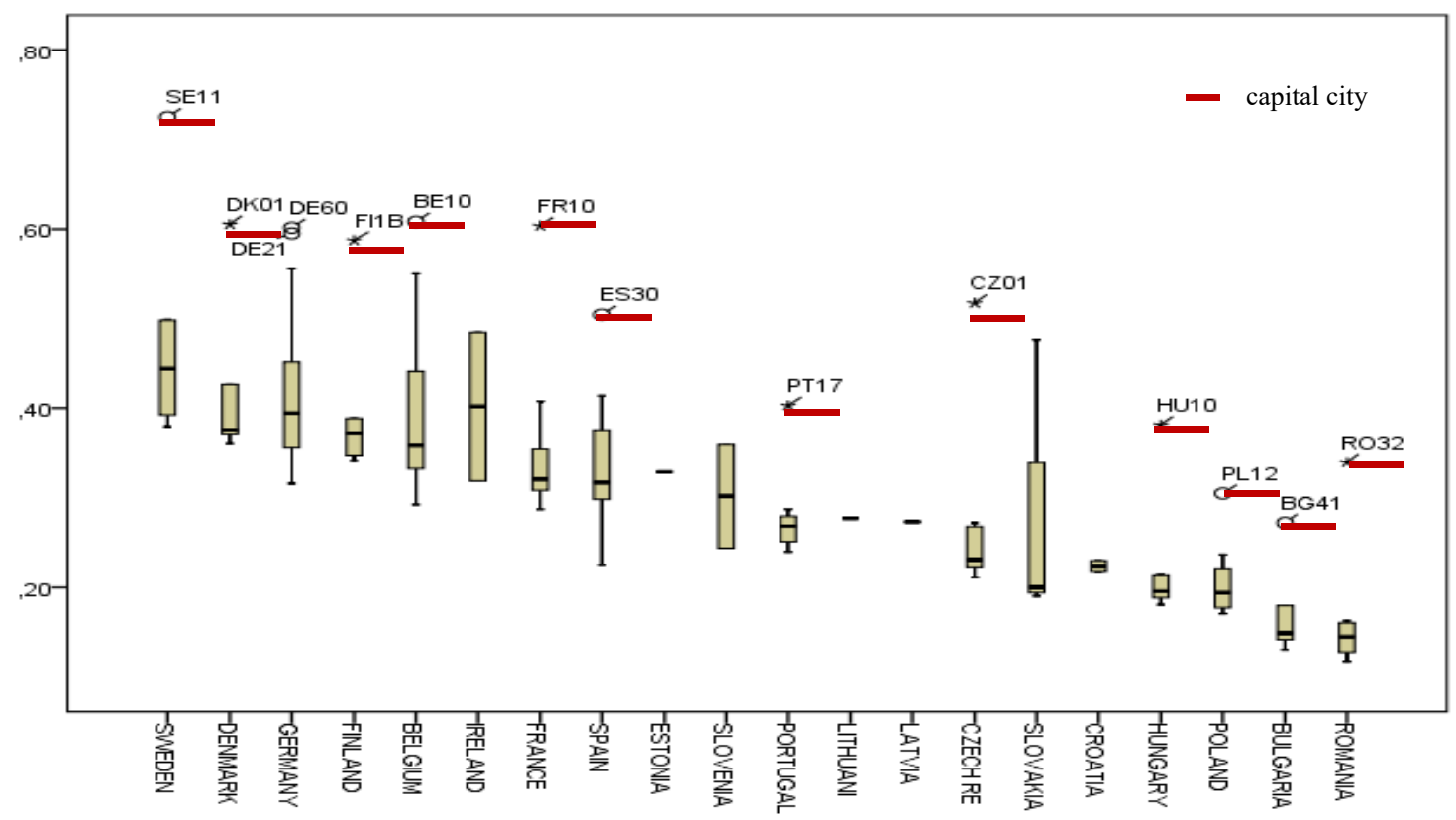

Figure 2. Boxplot analysis of the EIRC_PCA by country. Source: authors' own.

Decreasing value in European creative potential is also evident, wherein countries in the centre and north appear in the leading positions, and countries in the east appear in the lower positions, thereby evidencing the link between creative potential and the level of economic development, since the countries which lag further behind in relative terms also display the least capacity to develop creativity.

In addition, the range of the indicator's regional dispersion in the countries displaying high creative potential is extensive, thus reflecting major domestic imbalances. In contrast, the countries with the lowest values in the indicator also evidence a lower degree of regional dispersion. Similar results emerge with the analysis of the boxplot dispersion for the EIRC_DEA and EIRC_DP2 indicators. These results bears out one of the main contributions of our research, namely the notion that creativity follows technology gap models at a spatial level. In other words, creative potential is concentrated and triggers major spatial disparities in countries where creative performance is more intense. Creativity thus proves to be a source of new regional imbalances.

As regards the reliability and robustness of the EIRC results, it is necessary to take into account each method's weightings since, according to Greco et al. [55] these may lead to different results. Table 4 shows the weights allocated to each dimension for the three aggregation methods used. The EIRC_PCA estimates the weights through the product of the squared saturations and the value of the variance explained, and it can also be seen to allocate a greater weight to the dimension of Cultural and Creative Industries and to the dimension of Talent. The average weights resulting from the DEA method are also shown, with the Liveability and Cultural and Creative Industries dimensions being the most weighted. Finally, the DP2 method allows us to observe the order of entrance of the dimensions in the final indicator as well as the amount of information each contributes to the composite indicator. The first dimension in order of entrance is Cultural and Creative Industries, which contributes $100 \%$ of its information, with Talent second, contributing $24 \%$ of the information. In the three methods, the Cultural and Creative Industries dimension makes a major contribution in terms of weight, with the weight structure of the EIRC_PCA and EIRC_DP2 indicators proving to be more similar, while EIRC_DEA displays greater variability. This bears out the notion that regional creative potential is based on the pre-existence of a powerful creative cultural industry, in addition to evidencing the need for the accumulation of talent and innovation, in the line posited by Cerisola [14], Backman and Nilsson [18], Ortega-Villa and Ley-García [21] and Rodrigues and Franco [22]. 
Table 4. Weights and results of aggregation methods.

\begin{tabular}{lccccc}
\hline & \multicolumn{2}{c}{ EIRC_PCA } & \multicolumn{2}{c}{ EIRC_DEA } & \multicolumn{2}{c}{ EIRC_DP2 } \\
\hline Dimensions & Square Saturations & Weights $^{\text {a }}$ & Average Weights $^{\mathbf{b}}$ & $\left.\right|_{\mathbf{r} \mid} \mathbf{c}^{\mathbf{c}}$ & $\mathbf{( 1 - R 2 )}$ \\
\hline D1. Talent & 0.862 & 0.2035 & 0.618 & 0.919 & 0.2452 \\
D2. Openness and Tolerance & 0.728 & 0.1717 & 0.234 & 0.824 & 0.4033 \\
D3. Culture & 0.318 & 0.0751 & 0.228 & 0.640 & 0.4722 \\
D4. Technology and Innovation & 0.766 & 0.1807 & 0.561 & 0.841 & 0.3534 \\
D5. Cultural and Creative Industries & 0.876 & 0.2068 & 0.630 & 0.965 & 1 \\
D6. Liveability & 0.687 & 0.1622 & 0.693 & 0.776 & 0.3210 \\
\hline
\end{tabular}

Notes: ${ }^{\mathrm{a}} \mathrm{KMO}=0.853$; Bartlett Sphericity Test $=876.012 ; \mathrm{gl}=15 ; p<0.000$; total variance explained $=70.62 \% .{ }^{\mathrm{b}}$ Given that the DEA method does not require all regions to be weighted in the same way for each dimension, here we reflect the average weights of each dimension for all the regions in order to gain an approximate idea of the weighting structure. ${ }^{c}$ The correlation coefficient determines the order in which the partial indicators access the synthetic indicator, whilst the correcting factor provides information concerning the amount of information each dimension contributes to the composite indicator. Source: authors' own.

Another way to assess indicator reliability involves comparing the order of the results obtained. To do this, and based on the classifications obtained by the regions in the three indicators, we estimated rank correlation coefficients, following the methodological guidelines also applied in other works of Silva et al. and Kuc-Czarnecka et al. [76,77]. In all instances, coefficients are high $(>0.70)$ and statistically significant, thus indicating that the variability in the positions each region occupies in the ranking in accordance with the weighting criterion is fairly negligible and that this therefore has little relevance when interpreting the final result. This confirms the robustness and reliability of the synthetic indicator of creativity for the three methods used. As already pointed out, the EIRC_PCA and EIRC_DP2 indicators are more similar, in line with Somarriba and Pena [62]. Nevertheless, if we take into account the average ranking of the three indicators for each region, the resulting order of the EIRC_PCA proves to be technically superior in comparative terms and displays greater discriminant capacity in this work, obtaining a Spearman coefficient of 0.989 (Table 5). However, the differences between the three indicators are, broadly speaking, scant.

Table 5. Rho Spearman correlation coefficient and tau-b Kendall.

\begin{tabular}{|c|c|c|c|c|}
\hline \multicolumn{5}{|c|}{ Rho Spearman Correlation Coefficient } \\
\hline & EIRC_PCA & EIRC_DEA & EIRC_DP2 & Rk average \\
\hline EIRC_PCA & 1 & & & \\
\hline EIRC_DEA & $0.917 * *$ & 1 & & \\
\hline EIRC_DP2 & $0.982 * *$ & $0.891^{* *}$ & 1 & \\
\hline Rk average & $0.989 * *$ & $0.956^{* *}$ & $0.980 * *$ & 1 \\
\hline \multicolumn{5}{|c|}{ Tau-b Kendall Correlation Coefficient } \\
\hline & EIRC_PCA & EIRC_DEA & EIRC_DP2 & Rk average \\
\hline EIRC_PCA & 1 & & & \\
\hline EIRC_DEA & $0.773^{* *}$ & 1 & & \\
\hline EIRC_DP2 & $0.897^{* *}$ & $0.734^{* *}$ & 1 & \\
\hline Rk average & $0.929 * *$ & $0.837^{* *}$ & $0.892 * *$ & 1 \\
\hline
\end{tabular}

Finally, we tested the consistency and external validity of the composite indicators and found similarities to other existing indicators with which they hold a certain relation with theoretical justification [55]. Taking the EIRC_PCA, its external validity was compared to regional GDP per capita and the European Regional Competitiveness Index (RCI), given the close ties the creative economy has with economic development and regional competitiveness, as shown in Alexy et al. [24], Correa et al. [2] and Sleuwaegen and Ramboer [5]. RCI was first estimated by the European Commission in 2010, and is published each three years. It monitors and assesses European region's level of development 
and competitiveness. The correlation was calculated using RCI data for 2016. The results yielded correlations of 0.927 and 0.888 , respectively, which were significant at the $1 \%$ confidence level, thus supporting the external validity of our indicator. It should be pointed out that these results do not aim to establish causal relations but are presented merely in an effort to test the external validity of the data gathered for estimating our indicator.

\subsection{Spatial Analysis of the EIRC in European Regions}

Figures 3-5 show the performance of European regions in the creative economy for each of the three indicators obtained, classified in quartiles. Regions shown in darker colours display greater values in the indicator and mainly correspond to the regions of the ranking in Table 3, whereas the regions shown in lighter colours display lower values. Regions in white do not form part of the sample.

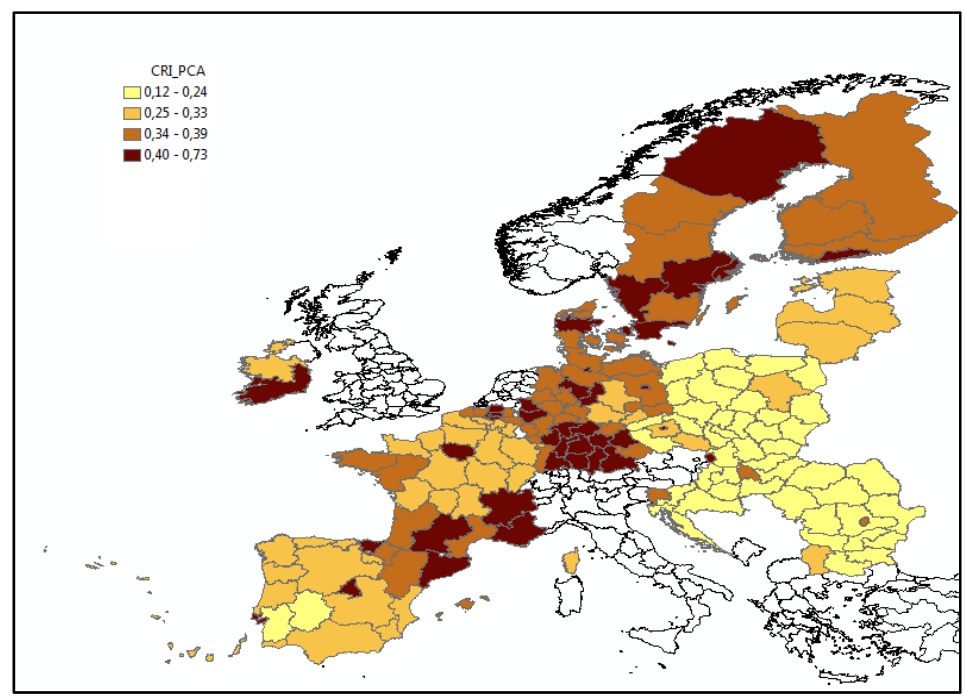

Figure 3. European Indicator of Regional Creativity by Principal Component Analysis (EIRC_PCA). Source: authors' own.

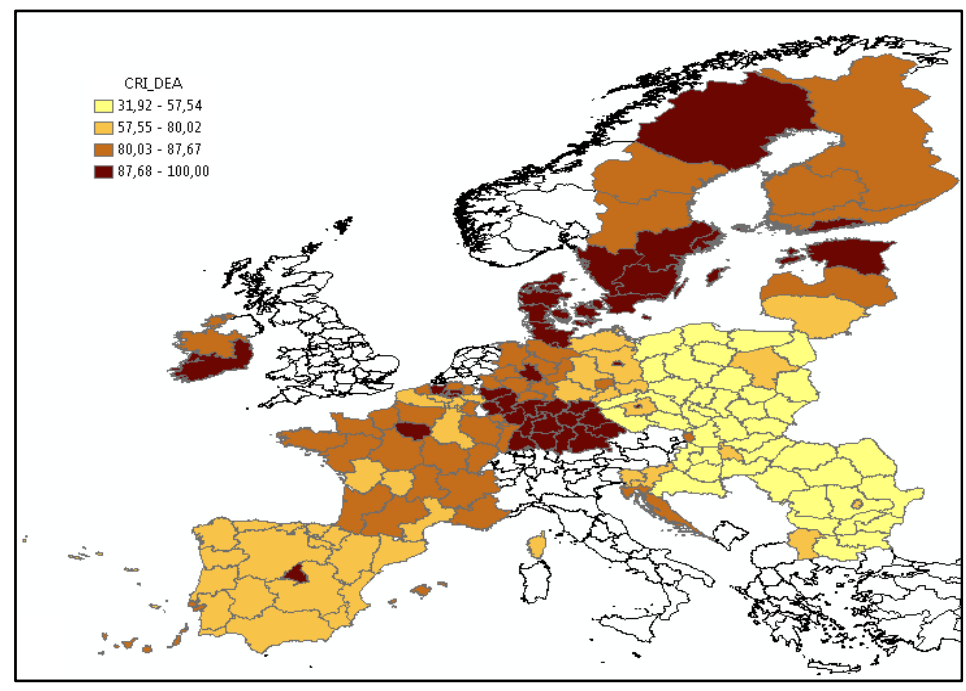

Figure 4. European Indicator of Regional Creativity by DEA (EIRC_DEA). Source: authors’ own. 


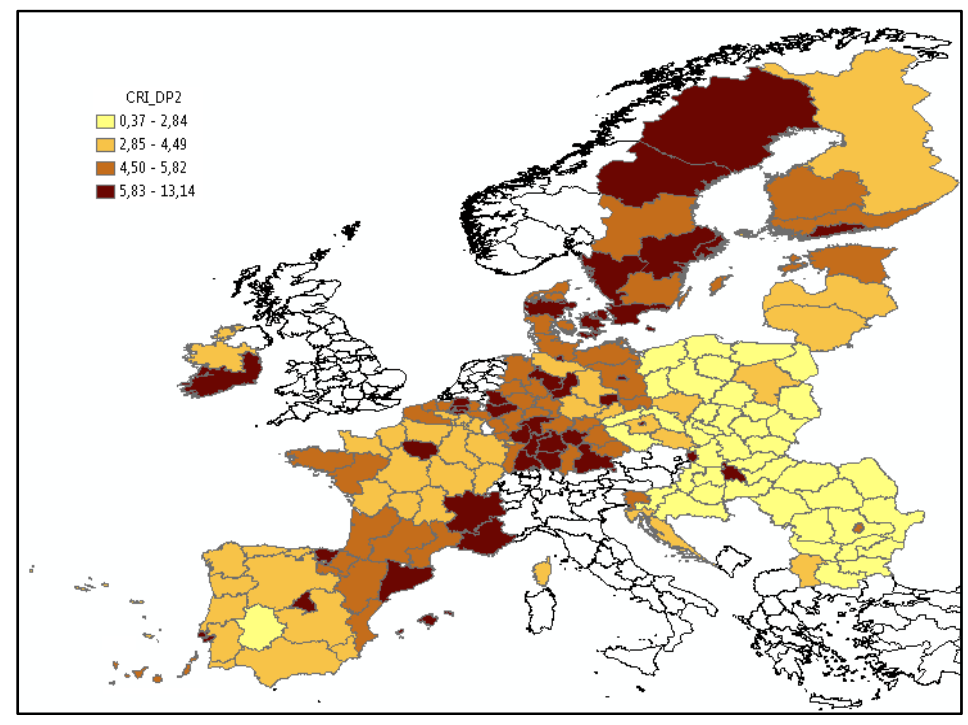

Figure 5. European Indicator of Regional Creativity by DP2 (EIRC_DP2). Source: authors'own.

The maps provide a more accurate picture of the distribution of creative potential in Europe, where the worst levels of creativity are seen in regions in southern and western Spain together with Portugal and regions in countries in eastern Europe. In contrast, the highest levels of creativity are concentrated particularly in central-east European regions, specifically Belgium and Germany, together with the Nordic countries such as Denmark, Sweden and Finland, as well as certain regions of the Czech Republic and Slovakia, northern Spain, as well as many regions in France and southern Ireland. Prominent once again are the regions which are home to national capital cities [25] and, in more general terms, regions in the south of Germany and Sweden. Likewise, the maps of the indicator in terms of the PCA and DP2 method are more similar [62], although the results vis-à-vis concentration and distribution also hold with regard to EIRC_DEA. This concentration pattern shown by our indicator is characteristic of creative activities at different territorial levels and when applying different forms of measuring, as also shown by Boix et al. [6] in a comparative analysis between European countries, Bertacchini and Borrione [26] in urban areas and Italian regions and Martín et al. [16] for regions in the United States. Moreover, several works such as those of Boix et al. [78] and Boal and Herrero [71] have reported high concentration coefficients in the cultural and creative sector in specific regions of Italy and Spain.

In light of the results, it is worth asking whether these spatial patterns of creativity give rise to territorial dependence and economies of agglomeration. Spatial dependence points to the existence of spatial autocorrelation amongst regions; in other words, a region's creative performance may be linked to the creativity of its neighbours, in line with other works [6,26,71]. To verify this, we estimated Moran's I for the three composite indicators of creativity and its dimensions (Table 6). These showed positive and significant results, pointing to the existence of spatial dependence regardless of the aggregation method used. We can thus confirm that creativity is not distributed randomly amongst European regions and that high and low values of the indicator are grouped spatially. Geographic proximity does therefore prove to be a crucial factor, with the spatial externalities of creativity feeding the creative potential of European regions that are close to one another, as has also been evidenced in Dominicis et al. [79] thus highlighting the importance of economies of agglomeration in this sector $[71,80,81]$. Figure 6 shows the spatial dispersion diagram of the EIRC_PCA, where it can be seen that most regions are located in quadrants displaying positive spatial autocorrelation. Quadrants I and II reflect positive spatial autocorrelation, while quadrants II and IV reflect negative spatial autocorrelation. Identical spatial dependence results may be found for the underlying dimensions of the composite indicator, with the exception of the cultural dimension, whose result gives a nonsignificant value. It is conceivable that regions' cultural capital, measured as a part of the supply (cinema, theatres and libraries) and demand 
(cinema and museums) of culture, plays a part in regional creative potential but that it is distributed randomly and displays no established spatial pattern.

Table 6. Spatial autocorrelation analysis.

\begin{tabular}{lcc}
\hline Indicators & Moran's I & Z-score \\
\hline EIRC_PCA & 0.5594 & $10.41^{* * *}$ \\
EIRC_DEA & 0.8089 & $14.76^{* * *}$ \\
EIRC_DP2 & 0.4468 & $8.29^{* * *}$ \\
\hline Dimensions & Moran's I & Z(I) \\
\hline Talent & 0.4027 & $7.72^{* * *}$ \\
Openness and Tolerance & 0.6851 & $12.78^{* * *}$ \\
Culture & 0.0617 & $1.25^{* *}$ \\
Technology and Innovation & 0.5118 & $9.53^{* * *}$ \\
Cultural and Creative Industries & 0.3200 & $5.98^{* * *}$ \\
Liveability & 0.8907 & $16.77^{* * *}$ \\
\hline
\end{tabular}

${ }^{* * *} p$-value $=0.001$. Source: authors'own.

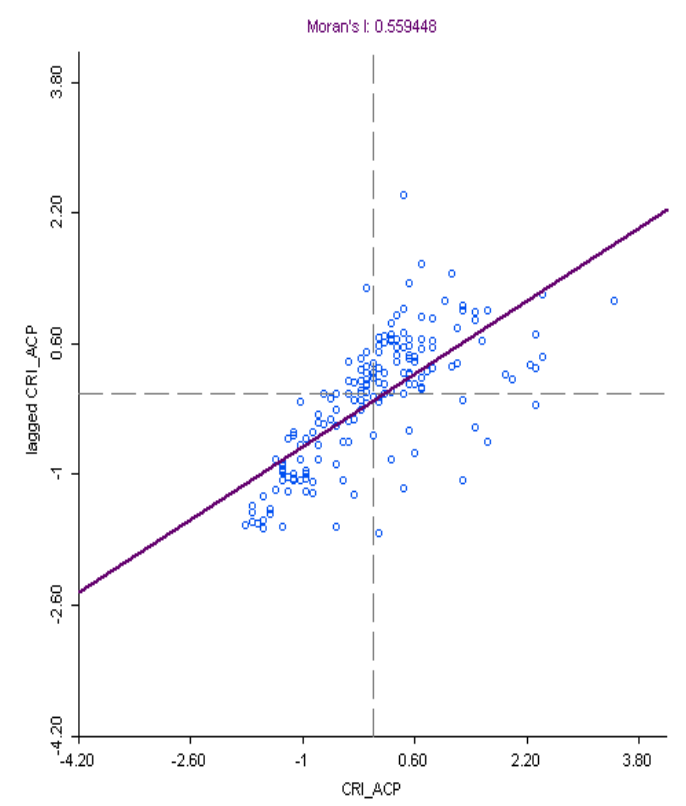

Figure 6. Moran scatter plot. Source: authors'own.

Figure 7 shows the spatial patterns of the EIRC_PCA indicator and its statistically significant hotspots (spatial clusters with high values) and cold spots (spatial clusters with low values), based on the Getis-Ord $\mathrm{Gi}^{*}$ statistic. These are spatial groupings formed by those regions displaying similar values (high or low) in terms of the territorial clusters and which are identified thanks to their geographical proximity and the existence of spatial autocorrelation between regions, based on the creativity indicator. This is a different approach for determining spatial clusters to the one used by Rodrigues and Franco [82], who employ hierarchical clustering for this purpose. 


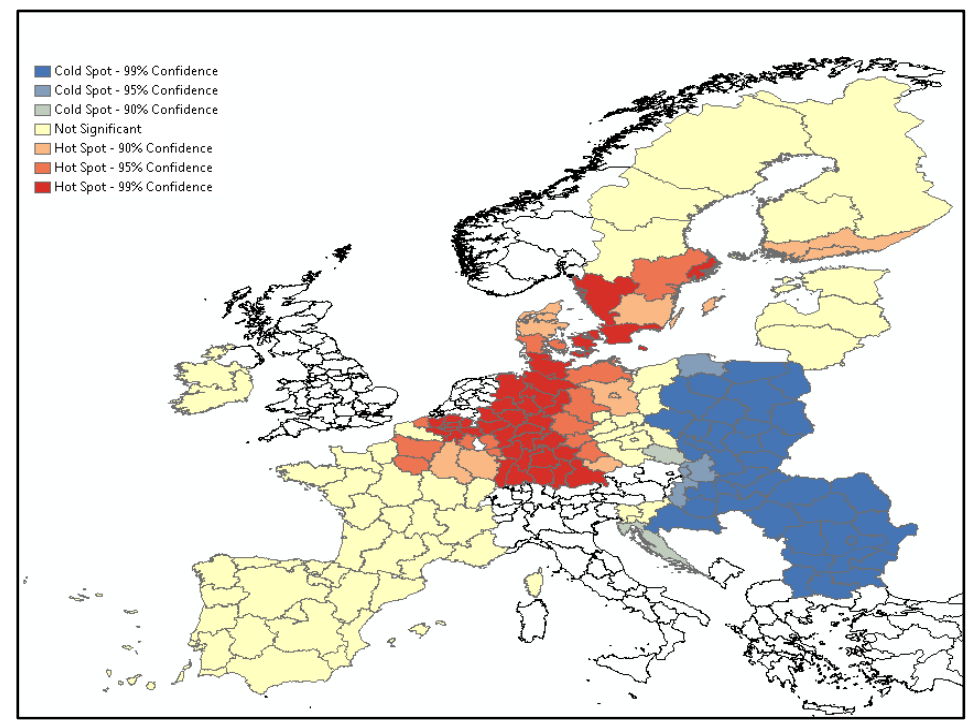

Figure 7. Regional creativity clusters. Source: authors' own.

Regions shaded in red evidence a strong likelihood of spatial dependence in the indicator's high value; in other words, better performance in the creative economy, and they are mainly located in Germany, Belgium, Denmark, northern France and the south of the Nordic countries. In contrast, regions shaded in blue display significant spatial interaction in high values, with poorer levels of creativity, located in eastern Europe (Bulgaria, Croatia, Slovakia, Hungary, Poland, the Czech Republic and Romania). This distribution of spatial clusters of the multidimensional synthetic indicator is similar to the results obtained by Boix et al. [80] for Europe, identifying creative clusters using geo-statistical algorithm and firm data.

\section{Discussion and Conclusions}

The importance of the creative economy in regions' economic development has aroused interest in measuring its scope by estimating composite indicators of creativity. The main existing cultural and creative indicators are applied to countries or to large urban areas, whereas works that consider the regional level and a broad sample of countries remain few and far between. As a result, in this work we have built composite indicators of creativity at a (NUTS 2) regional disaggregation level for a sample of $20 \mathrm{EU}$ countries, in an effort to enhance measurement of creative potential and to gain an insight into territorial behaviour. Considering the principal underlying dimensions of creativity pinpointed subsequent to a review of the literature on creative indicators, we construct the index based on six creativity vectors, focusing particularly on compiling participation and cultural endowment indicators which are in turn grounded on a wide compilation of primary variables. We use different aggregation methods in an effort to gauge their robustness and reliability, and we assess the indicator's distribution and spatial patterns. These are three of the main methodological contributions our research makes.

One of the most widely debated issues when constructing composite indicators is deciding what weight should be assigned to each partial indicator since, depending on the aggregation method used, the final indicator may differ. As a result, we use three aggregation methods based on the BoD hypothesis, which means that the weightings stem from the actual underlying structure of data, thereby allowing data intensity to speak for itself. The rank correlation coefficients for the classifications obtained using the three methods were positive and significant, such that the choice of one aggregation method or another has little impact on our indicator, therefore making the result robust and reliable. In the three methods, the dimension concerning the scope of the cultural and creative industries, together with the accumulation of talent and the technological level, seem to carry greater weight in terms of the regional creativity indicator. 
As regards the empirical results, the indicator evidences an unequal distribution in European regions, with different territorial patterns and substantial spatial disparity emerging, and in which strong polarisation between regions in central and northern Europe on the one hand, and regions in eastern and southern Europe, on the other, can be seen. In turn, we observe major disparities between regions in the same country, with these being more acute the greater the country's creative performance in overall terms. This shows that creativity functions as a technological gap; in other words, creativity triggers greater regional imbalances wherever it appears more intensely. This concentration of creative potential and the gap it leads to when compared to other regions is particularly evident in areas that are home to national capitals, which emerge as the extreme points of the indicator's regional distribution in all countries, with the exception of Germany. We have also been able to verify that the European distribution of the creativity indicator coincides with regional economic disparities and exhibits a high correlation with per capita GDP and the index of regional competitiveness drawn up by the European Commission, thereby also confirming the external validity of our indicator. Although an analysis of causal relations lies outside the scope of this work, these results strengthen the belief posited in the literature regarding the importance of the creative economy in regions' economic development and sustainability. Nevertheless, it would also appear that creativity may prove to be a new source of spatial disparities given its high tendency to concentrate and the gap it generates when compared to spaces that offer less creative potential.

A further empirical contribution this work makes involves considering geographic proximity and the interactions between regions in their creative performance. Applying spatial autocorrelation techniques has enabled us to pinpoint the existence of positive spatial dependence in the regional creativity indicator. We are therefore in a position to state that spatial externalities feed the creative economy of adjacent regions and that the likelihood of one region obtaining a higher value in the indicator is not independent from the values of its neighbouring regions, thereby triggering the formation of spatial clusters of creativity. Clusters displaying the greatest creative performance are mainly to be found in northern and central Europe (Germany, Belgium, northern France, Denmark and Sweden), whereas the clusters with the lowest creative performance are located in eastern European regions (Bulgaria, Slovakia, Hungary, Poland and Romania). Spatial and geographic proximity thus emerge as crucial and determinant factors of regional creative stock.

The practical utilities of a research which is basically instrumental, such as our study, therefore lie both in the contribution made to current knowledge concerning how regional creative potential is distributed over a broad sample of European countries as well as the methodological design of composite indicators of creativity over a wide base of primary variables and partial dimensions, applying endogenous weighting criteria. As regards regional policy implications, the results of this work may prove useful vis-à-vis assessing the dynamics of the creative economy in European regions. Creative indicators provide a useful tool for monitoring the planning of regional policies and for gauging their effectiveness. As a comparative measuring tool, they help pinpoint examples of good practices that serve as a reference for political decision making at the regional scale. Faced with the challenge of revitalising regional development through creative and innovative processes, as well as of reducing territorial differences in an effort to achieve greater regional convergence, the results obtained provide vital information for policymakers to evaluate the outcomes of the policies implemented and to focus regional policy strategy. In this regard, and given that the importance of the dimensions of talent, innovation, and scope of the cultural and creative industry when constructing the composite indicator of creativity have also been shown, the most efficient regional policies should be grounded on three complementary vertices: promoting training and attracting human capital; encouraging entrepreneurship and the innovation capacity; and, finally, fostering environmental cultural assets, not only in terms of upstream cultural amenities but also when developing new culturally and downstream based creative market products.

Nevertheless, certain limitations which are put forward as future challenges to be improved do emerge. On the one hand, improving data availability at a regional scale would enable a greater 
number of variables and dimensions to be included. There is also a need to extend the number of EU countries. In addition, it would prove enlightening to explore which determinants drive the location of cultural and creative industries, which would therefore provide further complementary information to be included in the indicators when fostering creative environments.

Author Contributions: All authors contributed equally to this work. Both authors have read and approved the final manuscript.

Funding: This study was supported by the Regional Ministry of Education at the Regional Government of Castile and Leon (Spain) (project no VA012G19) and has benefitted from a research stay at the School of Technology and Management of the Polytechnic Institute of Braganza, funded by the University of Valladolid under the 2019 Teaching Staff Mobility Programme.

Acknowledgments: The authors would like to thank participants at the $9^{\text {th }}$ European Workshop on Applied Cultural Economics, Copenhagen (2019), and the XXX Portuguese-Spanish Conference on Scientific Management, Braganza, Portugal (2020), for comments and discussion on a preliminary version of the paper. The usual disclaimer applies.

Conflicts of Interest: The authors declare no conflict of interest.

\section{Appendix A}

Table A1. Scores of EIRC indicators in European regions NUTS 2.

\begin{tabular}{|c|c|c|c|c|}
\hline & & EIRC_PCA & EIRC_DEA & EIRC_DP2 \\
\hline BE & Belgium & & & \\
\hline BE10 & Région de Bruxelles-Capitale & 0.608 & 100.000 & 12.307 \\
\hline BE21 & Prov. Antwerpen & 0.412 & 85.797 & 6.184 \\
\hline BE22 & Prov. Limburg & 0.355 & 82.723 & 5.198 \\
\hline BE23 & Prov. Oost-Vlaanderen & 0.394 & 87.946 & 5.471 \\
\hline BE24 & Prov. Vlaams-Brabant & 0.470 & 91.547 & 6.741 \\
\hline BE25 & Prov. West-Vlaanderen & 0.359 & 85.439 & 5.092 \\
\hline BE31 & Prov. Brabant Wallon & 0.550 & 88.611 & 8.755 \\
\hline BE32 & Prov. Hainaut & 0.292 & 74.782 & 3.825 \\
\hline BE33 & Prov. Liège & 0.344 & 77.600 & 4.878 \\
\hline BE34 & Prov. Luxembourg & 0.321 & 81.646 & 4.475 \\
\hline BE35 & Prov. Namur & 0.321 & 80.021 & 4.288 \\
\hline BG & Bulgaria & & & \\
\hline BG31 & Severozapaden & 0.131 & 31.916 & 0.601 \\
\hline BG32 & Severen tsentralen & 0.142 & 34.417 & 1.024 \\
\hline BG33 & Severoiztochen & 0.180 & 43.589 & 1.480 \\
\hline BG34 & Yugoiztochen & 0.152 & 35.156 & 1.049 \\
\hline BG41 & Yugozapaden & 0.272 & 62.541 & 3.179 \\
\hline BG42 & Yuzhen tsentralen & 0.146 & 35.587 & 0.888 \\
\hline HR & Croatia & & & \\
\hline HR03 & Jadranska Hrvatska & 0.230 & 81.299 & 3.475 \\
\hline HR04 & Kontinentalna Hrvatska & 0.217 & 53.839 & 2.842 \\
\hline $\mathrm{CZ}$ & Czech Republic & & & \\
\hline CZ01 & Praha & 0.517 & 90.115 & 10.208 \\
\hline CZ02 & Strední Cechy & 0.264 & 59.825 & 3.013 \\
\hline CZ03 & Jihozápad & 0.236 & 57.123 & 2.810 \\
\hline CZ04 & Severozápad & 0.211 & 53.435 & 2.227 \\
\hline CZ05 & Severovýchod & 0.222 & 56.337 & 2.371 \\
\hline CZ06 & Jihovýchod & 0.272 & 57.541 & 3.443 \\
\hline CZ07 & Strední Morava & 0.222 & 55.108 & 2.346 \\
\hline CZ08 & Moravskoslezsko & 0.226 & 54.311 & 2.537 \\
\hline
\end{tabular}


Table A1. Cont.

\begin{tabular}{|c|c|c|c|c|}
\hline & & EIRC_PCA & EIRC_DEA & EIRC_DP2 \\
\hline DK & Denmark & & & \\
\hline DK01 & Hovedstaden & 0.605 & 97.716 & 9.836 \\
\hline DK02 & Sjælland & 0.376 & 98.555 & 6.446 \\
\hline DK03 & Syddanmark & 0.372 & 88.098 & 4.844 \\
\hline DK04 & Midtjylland & 0.426 & 90.745 & 5.948 \\
\hline DK05 & Nordjylland & 0.361 & 87.888 & 4.980 \\
\hline EE & Estonia & & & \\
\hline EE00 & Eesti & 0.329 & 99.294 & 5.325 \\
\hline FI & Finland & & & \\
\hline FI19 & Länsi-Suomi & 0.388 & 83.551 & 4.928 \\
\hline FI1B & Helsinki-Uusimaa & 0.587 & 94.757 & 8.938 \\
\hline FI1C & Etelä-Suomi & 0.372 & 82.587 & 4.654 \\
\hline FI1D & Pohjois- ja Itä-Suomi & 0.341 & 80.553 & 3.950 \\
\hline FI20 & Åland & 0.348 & 94.475 & 3.836 \\
\hline FR & France & & & \\
\hline FR10 & Île de France & 0.604 & 100.000 & 11.330 \\
\hline FR21 & Champagne-Ardenne & 0.289 & 79.074 & 3.822 \\
\hline FR22 & Picardie & 0.308 & 80.812 & 4.043 \\
\hline FR23 & Haute-Normandie & 0.320 & 82.090 & 4.461 \\
\hline FR24 & Centre & 0.328 & 81.611 & 4.492 \\
\hline FR25 & Basse-Normandie & 0.310 & 80,432 & 4.002 \\
\hline FR26 & Bourgogne & 0.305 & 80.759 & 3.978 \\
\hline FR30 & Nord - Pas-de-Calais & 0.308 & 77.519 & 4.521 \\
\hline FR41 & Lorraine & 0.309 & 80.186 & 4.001 \\
\hline FR42 & Alsace & 0.384 & 84.697 & 5.785 \\
\hline FR43 & Franche-Comté & 0.317 & 82.024 & 4.351 \\
\hline FR51 & Pays de la Loire & 0.343 & 82.892 & 4.723 \\
\hline FR52 & Bretagne & 0.342 & 81,828 & 4.771 \\
\hline FR53 & Poitou-Charentes & 0.317 & 79.823 & 4.327 \\
\hline FR61 & Aquitaine & 0.355 & 81.490 & 5.121 \\
\hline FR62 & Midi-Pyrénées & 0.398 & 82,297 & 5.768 \\
\hline FR63 & Limousin & 0.303 & 79.113 & 4.233 \\
\hline FR71 & Rhône-Alpes & 0.408 & 86.199 & 6.034 \\
\hline FR72 & Auvergne & 0.321 & 81.069 & 4.054 \\
\hline FR81 & Languedoc-Roussillon & 0.343 & 76.641 & 4.988 \\
\hline FR82 & Provence-Alpes-Côte d'Azur & 0.402 & 81.663 & 6.414 \\
\hline FR83 & Corse & 0.287 & 76.923 & 4.485 \\
\hline DE & Germany & & & \\
\hline DE11 & Stuttgart & 0.517 & 95.807 & 7.440 \\
\hline DE12 & Karlsruhe & 0.480 & 92,525 & 7.081 \\
\hline DE13 & Freiburg & 0.427 & 93.207 & 5.948 \\
\hline DE14 & Tübingen & 0.451 & 94.434 & 6.310 \\
\hline DE21 & Oberbayern & 0.595 & 100.000 & 9.469 \\
\hline DE22 & Niederbayern & 0.357 & 90.361 & 4.886 \\
\hline DE23 & Oberpfalz & 0.395 & 90.060 & 5.266 \\
\hline DE24 & Oberfranken & 0.387 & 88,811 & 5.348 \\
\hline DE25 & Mittelfranken & 0.477 & 92.460 & 7.363 \\
\hline
\end{tabular}


Table A1. Cont.

\begin{tabular}{|c|c|c|c|c|}
\hline & & EIRC_PCA & EIRC_DEA & EIRC_DP2 \\
\hline DE26 & Unterfranken & 0.407 & 90.653 & 5.575 \\
\hline DE27 & Schwaben & 0.407 & 92.768 & 5.818 \\
\hline DE30 & Berlin & 0.556 & 90.976 & 9.799 \\
\hline DE40 & Brandenburg & 0.351 & 79.346 & 4.626 \\
\hline DE50 & Bremen & 0.456 & 86.453 & 7.580 \\
\hline DE60 & Hamburg & 0.602 & 95.338 & 10.805 \\
\hline DE71 & Darmstadt & 0.512 & 92.687 & 8.014 \\
\hline DE72 & Gießen & 0.386 & 87.666 & 5.255 \\
\hline DE73 & Kassel & 0.361 & 85.439 & 4.977 \\
\hline DE80 & Mecklenburg-Vorpommern & 0.340 & 76.534 & 4.714 \\
\hline DE91 & Braunschweig & 0.424 & 86.381 & 5.844 \\
\hline DE92 & Hannover & 0.414 & 86.052 & 6.027 \\
\hline DE93 & Lüneburg & 0.347 & 87.665 & 4.461 \\
\hline DE94 & Weser-Ems & 0.343 & 86.183 & 4.524 \\
\hline DEA1 & Düsseldorf & 0.434 & 87.117 & 6.749 \\
\hline DEA2 & Köln & 0.472 & 89.112 & 7.404 \\
\hline DEA3 & Münster & 0.370 & 86.564 & 5.227 \\
\hline DEA4 & Detmold & 0.394 & 89.374 & 5.574 \\
\hline DEA5 & Arnsberg & 0.375 & 85.886 & 5.311 \\
\hline DEB1 & Koblenz & 0.349 & 88.718 & 4.704 \\
\hline DEB2 & Trier & 0.374 & 89.857 & 5.120 \\
\hline DEB3 & Rheinhessen-Pfalz & 0.429 & 89.833 & 6.134 \\
\hline DEC0 & Saarland & 0.344 & 83.176 & 4.520 \\
\hline DED2 & Dresden & 0.391 & 79.714 & 5.646 \\
\hline DED4 & Chemnitz & 0.316 & 77.279 & 3.938 \\
\hline DED5 & Leipzig & 0.395 & 80.391 & 5.863 \\
\hline DEE0 & Sachsen-Anhalt & 0.318 & 76.428 & 4.027 \\
\hline DEF0 & Schleswig-Holstein & 0.382 & 87.810 & 5.260 \\
\hline DEG0 & Thüringen & 0.332 & 78.158 & 4.220 \\
\hline HU & Hungary & & & \\
\hline HU10 & Közép-Magyarország & 0.381 & 77.342 & 6.924 \\
\hline HU21 & Közép-Dunántúl & 0.212 & 50,120 & 2,440 \\
\hline HU22 & Nyugat-Dunántúl & 0.214 & 50.268 & 2.558 \\
\hline HU23 & Dél-Dunántúl & 0.195 & 45.984 & 2.258 \\
\hline HU31 & Észak-Magyarország & 0.181 & 44.963 & 1.890 \\
\hline HU32 & Észak-Alföld & 0.182 & 45.819 & 1.928 \\
\hline HU33 & Dél-Alföld & 0.196 & 47.852 & 2.277 \\
\hline IE & Ireland & & & \\
\hline IE01 & Border, Midland and Western & 0.319 & 84.669 & 3.871 \\
\hline IE02 & Southern and Eastern & 0.485 & 97.565 & 8.303 \\
\hline LV & Latvia & & & \\
\hline LV00 & Latvija & 0.273 & 83.498 & 3.984 \\
\hline LT & Lithuania & & & \\
\hline LT00 & Lietuva & 0.277 & 65.572 & 3.834 \\
\hline PL & Poland & & & \\
\hline PL11 & Lódzkie & 0.217 & 51.974 & 2.145 \\
\hline PL12 & Mazowieckie & 0.305 & 61.002 & 4.243 \\
\hline PL21 & Malopolskie & 0.224 & 52.603 & 2.551 \\
\hline PL22 & Slaskie & 0.208 & 53.546 & 2.147 \\
\hline PL31 & Lubelskie & 0.178 & 48.890 & 1.513 \\
\hline
\end{tabular}


Table A1. Cont.

\begin{tabular}{|c|c|c|c|c|}
\hline & & EIRC_PCA & EIRC_DEA & EIRC_DP2 \\
\hline PL32 & Podkarpackie & 0.171 & 47.350 & 1.178 \\
\hline PL33 & Swietokrzyskie & 0.176 & 48.643 & 1.258 \\
\hline PL34 & Podlaskie & 0.174 & 49.092 & 1.227 \\
\hline PL41 & Wielkopolskie & 0.203 & 54.715 & 2.032 \\
\hline PL42 & Zachodniopomorskie & 0.193 & 50.994 & 1.975 \\
\hline PL43 & Lubuskie & 0.196 & 49.846 & 1.836 \\
\hline PL51 & Dolnoslaskie & 0.237 & 53.618 & 2.955 \\
\hline PL52 & Opolskie & 0.185 & 49.770 & 1.590 \\
\hline PL61 & Kujawsko-Pomorskie & 0.181 & 49.672 & 1.739 \\
\hline PL62 & Warminsko-Mazurskie & 0.176 & 48.566 & 1.576 \\
\hline PL63 & Pomorskie & 0.229 & 52.880 & 2.592 \\
\hline PT & Portugal & & & \\
\hline PT11 & Norte & 0.268 & 59.723 & 3.813 \\
\hline PT15 & Algarve & 0.287 & 77.643 & 4.007 \\
\hline PT16 & Centro & 0.254 & 66.313 & 3.235 \\
\hline PT17 & Á.Metropolitana de Lisboa & 0.403 & 80.671 & 7.275 \\
\hline PT18 & Alentejo & 0.240 & 61.803 & 3.405 \\
\hline PT20 & R.Autónoma dos Açores & 0.249 & 64.084 & 3.166 \\
\hline РT30 & R.Autónoma da Madeira & 0.271 & 67.012 & 4.270 \\
\hline RO & Romania & & & \\
\hline RO11 & Nord-Vest & 0.159 & 44.933 & 1.300 \\
\hline RO12 & Centru & 0.155 & 43.996 & 1.305 \\
\hline $\mathrm{RO} 21$ & Nord-Est & 0.126 & 40.102 & 0.594 \\
\hline $\mathrm{RO} 22$ & Sud-Est & 0.130 & 41.446 & 0.592 \\
\hline RO31 & Sud - Muntenia & 0.135 & 39.972 & 0.484 \\
\hline $\mathrm{RO} 32$ & Bucuresti - Ilfov & 0.339 & 67.238 & 5.223 \\
\hline RO41 & Sud-Vest Oltenia & 0.118 & 39.302 & 0.375 \\
\hline $\mathrm{RO} 42$ & Vest & 0.163 & 46.970 & 1.211 \\
\hline SK & Slovakia & & & \\
\hline SK01 & Bratislavský kraj & 0.477 & 86.864 & 9.240 \\
\hline SK02 & Západné Slovensko & 0.202 & 56.497 & 1.928 \\
\hline SK03 & Stredné Slovensko & 0.198 & 56.304 & 2.013 \\
\hline SK04 & Východné Slovensko & 0.190 & 52.881 & 1.758 \\
\hline SI & Slovenia & & & \\
\hline SI03 & Vzhodna Slovenija & 0.244 & 61.569 & 2.701 \\
\hline SI04 & Zahodna Slovenija & 0.360 & 65.742 & 5.572 \\
\hline ES & Spain & & & \\
\hline ES11 & Galicia & 0.301 & 64.085 & 3.912 \\
\hline ES12 & Principado de Asturias & 0.313 & 64.439 & 4.233 \\
\hline ES13 & Cantabria & 0.317 & 66.591 & 4.386 \\
\hline ES21 & País Vasco & 0.408 & 76.436 & 5.927 \\
\hline ES22 & Comunidad Foral de Navarra & 0.375 & 77.087 & 5.255 \\
\hline ES23 & La Rioja & 0.330 & 71.345 & 4.554 \\
\hline ES24 & Aragón & 0.338 & 71.434 & 4.751 \\
\hline ES30 & Comunidad de Madrid & 0.505 & 90.726 & 8.805 \\
\hline ES41 & Castilla y León & 0.298 & 66.682 & 4.049 \\
\hline $\mathrm{ES} 42$ & Castilla-la Mancha & 0.262 & 63.200 & 3.364 \\
\hline ES43 & Extremadura & 0.225 & 58.906 & 2.392 \\
\hline ES51 & Cataluña & 0.414 & 77.857 & 6.402 \\
\hline ES52 & Comunidad Valenciana & 0.328 & 73.770 & 4.788 \\
\hline
\end{tabular}


Table A1. Cont.

\begin{tabular}{llccc}
\hline & & EIRC_PCA & EIRC_DEA & EIRC_DP2 \\
\hline ES53 & Illes Balears & 0.379 & 86.120 & 6.075 \\
ES61 & Andalucía & 0.284 & 60.588 & 3.797 \\
ES62 & Región de Murcia & 0.290 & 63.352 & 3.954 \\
ES70 & Canarias & 0.308 & 81.459 & 4.583 \\
\hline SE & Sweden & & & \\
\hline SE11 & Stockholm & 0.725 & 100.000 & 13.140 \\
SE12 & Östra Mellansverige & 0.462 & 89.237 & 7.159 \\
SE21 & Småland med öarna & 0.391 & 88.804 & 5.565 \\
SE22 & Sydsverige & 0.497 & 89.758 & 7.626 \\
SE23 & Västsverige & 0.499 & 92.291 & 7.659 \\
SE31 & Norra Mellansverige & 0.379 & 85.771 & 5.732 \\
SE32 & Mellersta Norrland & 0.393 & 86.623 & 6.216 \\
SE33 & Övre Norrland & 0.425 & 88.517 & 6.580 \\
\hline
\end{tabular}

\section{References}

1. UNCTAD. Special Unit for South-South Cooperation-Creative Economy Report 2008, The Challenge of Assessing the Creative Economy: Towards Informed Policy-making; UNCTAD: Geneva, Switzerland, 2008.

2. Correa-Quezada, R.; Álvarez-García, J.; Del Río-Rama, M.D.C.; Maldonado-Erazo, C.P. Role of Creative Industries as a Regional Growth Factor. Sustainability 2018, 10, 1649. [CrossRef]

3. Rodrigues, M.; Franco, M. Composite Index to Measure Cities'Creative Performance: An Empirical Study in the Portuguese Context. Sustainability 2019, 11, 774. [CrossRef]

4. Scott, A.J. Creative cities: Conceptual issues and policy questions. J. Urban Aff. 2006, 28, 1-17. [CrossRef]

5. Sleuwaegen, L.; Ramboer, S. Regional competitiveness and high growth firms in the EU: The creativity Premium. App. Econ. 2019. [CrossRef]

6. Boix, R.; Lazzeretti, L.; Cappone, F.; Sánchez-Serra, D. The geography of creative industries in Europe: Comparing France, Great Britain, Italy and Spain. In Creative Industries and Innovation in Europe. Concepts, Measures and Comparative Case Studies, 1st ed.; Lazzeretti, L., Ed.; Routledge: Abingdon, UK, 2012.

7. Cooke, P.; Lazzeretti, L. Creative Cities, Cultural Clusters and Local Economic Development; Edward Elgar: Cheltenham, UK, 2008.

8. Valdivia, M.; Cuadrado-Roura, J.R. (Eds.) La economía de las actividades creativas: Una perspectiva desde España y México; CRIM-Universidad de Alcalá: Cuernavaca, México, 2017.

9. He, J.L.; Gebhardt, H. Space of creative industries: A case study of spatial characteristics of creative clusters in Shanghai. Eur. Plan. Stud. 2014, 22, 2351-2368. [CrossRef]

10. Florida, R. The Rise of the Creative Class: And How It's Transforming Work, Leisure, Community and Everyday Life; Basic Books: New York, NY, USA, 2002.

11. Florida, R.; Tinagli, I. Europe in the Creative Age; Demos: New York, NY, USA, 2004.

12. Boschma, R.A.; Fritsch, M. Creative class and regional growth: Empirical evidence from seven European countries. Econ. Geogr. 2009, 85, 391-423. [CrossRef]

13. Kemeny, T.; Nathan, M.; O'Brien, D. Creative differences? Measuring creative economy employment in the United States and the UK. Reg. Stud. 2019, 54, 377-387. [CrossRef]

14. Cerisola, S. Creativity and local economic development: The role of synergy among different talents. Pap. Reg. Sci. 2018, 97, 199-215. [CrossRef]

15. Kourtit, K.; Nijkamp, P. Creative actors and historical-cultural assets in urban regions. Reg. Stud. 2019, 53, 977-990. [CrossRef]

16. Martín, R.; Florida, R.; Pogue, M.; Mellander, C.; Gugler, P.; Ketels, C. Creativity, clusters and the competitive advantage of cities. Competitiveness. Rev. 2015, 25, 482-496. [CrossRef]

17. Cunningham, S.; Flew, T. Introduction to A Research Agenda for Creative Industries. In A Research Agenda for Creative Industries; Edward Elgar Publishing: Cheltenham, UK, 2019.

18. Backman, M.; Nilsson, P. The role of cultural heritage in attracting skilled individuals. J. Cult. Econ. 2018, 42, 111-138. [CrossRef] 
19. Lange, B.; Pradel I Miquel, M.; Garnizov, V. New governance, new geographic scales, new institutional settings. In Making Competitive Cities; Sako, M., Alan, M., Eds.; Wiley-Blackwell: Chichester, UK, 2010; pp. 306-326.

20. Foray, D.; Goddard, J.; Beldarrain, X.G.; Landabasco, M.; McCann, P.; Morgan, K.; Ortega-Argilés, R. Guide to Research and Innovation Strategies for Smart Specialisations (RIS 3); European Commission, DG Regional Policy: Luxembourg, 2012.

21. Ortega-Villa, L.M.; Ley-García, J. Analysis of cultural indicators: A comparison of their conceptual basis and dimensions. Soc. Indic. Res. 2018, 137, 413-439. [CrossRef]

22. Rodrigues, M.; Franco, M. Measuring the performance in creative cities: Proposal of a multidimensional model. Sustainability. 2018, 10, 4023. [CrossRef]

23. Correia, C.M.; Da Silva Costa, J. Measuring Creativity in the EU Member States. Investig. Reg. 2014, 30, 7-26.

24. Alexy, M.; Káčer, M.; Rehák, Š. Creative capacity of European countries. Hungarian Geogr. Bull. 2018, 67, 201-222. [CrossRef]

25. Montalto, V.; Moura, C.J.T.; Langedijk, S.; Saisana, M. Culture counts: An empirical approach to measure the cultural and creative vitality of European cities. Cities 2019, 89, 167-185. [CrossRef]

26. Bertacchini, E.; Borrione, P. The geography of the Italian creative economy: The special role of the design and craft-based industries. Reg. Stud. 2013, 47, 135-147. [CrossRef]

27. Porter, C.M.; Keith, M.G.; Woo, S.E. A meta-analysis of network positions and creative performance: Differentiaing creativity conceptualizations and measurement approaches. Psychol. Aesthet. Creat. Arts. 2020, 14, 50-67. [CrossRef]

28. Srakar, A.; Miroslav, V.; Copic, V. European cultural statistics in a comparative perspective: Index of economic and social condition of culture for the EU countries, 2005-2009. J. Cult. Econ. 2018, 42, 163-199. [CrossRef]

29. UNESCO. Measuring the Economic Contribution of Cultural Industries. A Review and Assessment of Current Methodological Approaches; UNESCO Institute for Statistics: Quebec, Canada, 2012.

30. European Commission. Guide to Eurostat Culture Statistics; Publications Office of the European Union: Lusembourg, 2018.

31. Stano, P.M.; Węziak-Białowolska, D. Measuring Cultural and Creative Activities in European cities: Challenges and Practical Problems with Existing Indices. Creat. Res. J. 2017, 29, 292-303. [CrossRef]

32. Knight Foundation, Americans for the Arts, the City of San Jose Office of Cultural Affairs and Cultural Initiatives Silicon Valley. Creative Community Index; Cultural Initiatives Silicon Valley: San Jose, CA, USA, 2002.

33. Picard, R.G.; Grönlund, M.; Toivonen, T. Means for Overall Assessment of Cultural Life and Measuring the Involvement of the Cultural Sector in the Information Society; Publications of the Ministry of Education, Finland: Helsinki, Finland, 2003.

34. Hong Kong Special Administrative Region Government. A Study on Creativity Index; HKSAR: Hong Kong, China, 2004.

35. Bowen, H.; Moesen, V.; Sleuwaegen, L. A Composite Index of the Creative Economy. Rev. Bus. Econ. 2008, 54, 375-397.

36. KEA European Affairs. The Economy of Culture in Europe; European Commission: Brussels, Belgium, 2009.

37. Hollanders, H.; Van Cruysen, A. Design, Creativity and Innovation: A Scoreboard Approach; PRO INNO Europe INNO METRICS, UNUMERIT, Maastricht Economic and Social Research and Training Centre on Innovation and Technology, Maastricht University: Maastricht, The Netherlands, 2009.

38. Kloudova, J.; Stehlikova, B. Creativity Index for the Czech Republic in Terms of Regional Similarities and Geographic Location. Econ. Manag. 2010, 15, 100-109.

39. Fleming Creative Consultancy. Introducing the Creative Grid: Connecting Creative Places for Global Competitiveness; Tom Fleming Creative Consultancy: London, UK, 2010.

40. Landry, C.; Hyams, J. The Creative City Index: Measuring the Creative Pulse of Your City; Comedia: London, UK, 2012.

41. Hartley, J.; Potts, J.; MacDonald, T. The CCI creative city index 2012. Cult. Scien. J 2012, 5, 1-138. [CrossRef]

42. Florida, R.; Mellander, C.; King, K. The Global Creativity Index 2015; Martin Prosperity Institute: Toronto, Canada, 2015.

43. Żelazny, R.; Pietrucha, J. Measuring innovation and institution: The creative economy index. Equilib. Q. J. Econ. Econ. Pol. 2017, 12, 43-62. [CrossRef] 
44. Barro, R. Education and Economic Growth; OECD: París, France, 2001.

45. Caniëls, M.C.; Van den Bosch, H. The role of higher education institutions in building regional innovation systems. Pap. Reg. Sci. 2011, 90, 271-286.

46. Bereitschaft, B.; Cammack, R. Neighborhood diversity and the creative class in Chicago. Appl. Geogr. 2015, 63, 166-183. [CrossRef]

47. Landry, C.; Bianchini, F. The Creative City; Demos: London, UK, 1995.

48. Throsby, D. Cultural Capital. J. Cult. Econ. 1999, 23, 3-12. [CrossRef]

49. Smithrim, K.; Upitis, R. Leaming through the arts: Lessons of engagement. Can. J. Educ. 2005, 28, $109-127$. [CrossRef]

50. Crociata, A.; Odoardi, I.; Agovino, M.; Sacco, P.L. A missing link? Cultural capital as a source of human capital: Evidence from Italian regional data. Ann. Reg. Sci. 2020, 64, 79-109. [CrossRef]

51. Pratt, A.C.; Jeffcutt, P. Creativity, innovation and the cultural economy: Snake oil for the twenty-first century? In Creativity, Innovation and the Cultural Economy; Pratt, A., Jeffcutt, P., Eds.; Routledge: London, UK, 2009.

52. Bakhshi, H.; McVittie, E.; Simmie, J. Creating Innovation: Do the Creative Industries Support Innovation in the Wider Economy; NESTA Research Report; NESTA: London, UK, 2008.

53. Durand, M. The OECD better life initiative: How's life? And the measurement of well-being. Rev. Income Wealth 2015, 61, 4-17. [CrossRef]

54. Nardo, M.; Saisana, M.; Saltelli, A.; Tarantola, S.; Hoffman, A.; Giovannini, E. Handbook on Constructing Composite Indicators: Methodology and User Guide; OECD publishing: París, France, 2008.

55. Greco, S.; Ishizaka, A.; Tasiou, M.; Torrisi, G. On the Methodological Framework of Composite Indices: A Review of the Issues of Weighting, Aggregation, and Robustness. Soc. Indic. Res. 2019, 141, 61-94. [CrossRef]

56. Paruolo, P.; Saisana, M.; Saltelli, A. Ratings and rankings: Voodoo or science? J. R. Stat. Soc. 2013, 176, 609-634. [CrossRef]

57. UNDP. Technical Notes. Human Development Report; UNDP: New York, NY, USA, 2014; Available online: http://hdr.undp.org/sites/default/files/hdr_2013_en_technotes.pdf (accessed on 5 March 2020).

58. Herrero-Prieto, L.C.; Boal-San Miguel, I.; Gómez-Vega, M. Deep-Rooted Culture and Economic Development: Taking the Seven Deadly Sins to Build a Well-Being Composite Indicator. Soc. Indic. Res. 2019, 144, 601-624. [CrossRef]

59. Lin, K.; Li, H. Mapping social quality clusters and its implications. Soc. Indic. Res. 2017, 134, 403-419. [CrossRef]

60. Murias, P.; Martínez, F.; Novello, S. Bienestar Económico Regional: Un Enfoque Comparativo entre Regiones Españolas e Italianas. Investig. Reg. 2009, 18, 5-36.

61. Domínguez Serrano, M.; Blancas Peral, F.J.; Guerrero Casas, F.M.; González Lozano, M. Una revisión crítica para la construcción de indicadores sintéticos. Revista de Métodos Cuantitativos para la Economía y la Empresa 2011, 11, 41-70.

62. Somarriba, N.; Pena, B. Synthetic indicators of quality of life in Europe. Soc. Indic. Res. 2009, 94, 115-133. [CrossRef]

63. Ram, R. Composite indices of physical quality of life, basic needs fulfillment as income. J. Dev. Econ. 1982, 11, 227-247. [CrossRef]

64. Huppert, F.A.; So, T.T. Flourishing across Europe: Application of a new conceptual framework for defining well-being. Soc. Indic. Res. 2013, 110, 837-861. [CrossRef]

65. Nicoletti, G.; Scarpetta, S.; Boylaud, O. Summary Indicators of Product Market Regulation with an Extension to Employment Protection Legislation; OECD Economics Department Working Paper, No. 226; OECD: Paris, France, 1999.

66. Gómez-Vega, M.; Picazo-Tadeo, A.J. Ranking world tourist destinations with a composite indicator of competitiveness: To weigh or not to weigh? Tourism Manage. 2019, 72, 281-291. [CrossRef]

67. Zhu, J. Multidimensional quality-of-life measure with an application to Fortune's best cities. Socio-Econ. Plan. Sci. 2001, 35, 263-284. [CrossRef]

68. De Jorge-Moreno, J.; De Jorge-Huertas, V. Measuring European cultural and creative cities efficiency: A metafrontier DEA approach. J. Econ. Stud. 2020. [CrossRef]

69. Pena, J.B. Problemas de la medición del Bienestar y Conceptos Afines. Una Aplicación al Caso Español; INE: Madrid, Spain, 1977. 
70. Martín, J.A.R.; Molina, M.D.M.H.; Fernández, J.A.S. An index of social and economic development in the community's objective-1 Regions of countries in Southern Europe. Eur. Plan. Stud. 2012, 20, 1059-1074. [CrossRef]

71. Boal, I.; Herrero, L.C. Where are the artists? Analysing economies of agglomeration in Castile and León, Spain. Pap. Reg. Sci. 2018, 97, 995-1017. [CrossRef]

72. Anselin, L. Spatial Econometrics: Methods and Models; Kluwer Academic Publishers: Dordrecht, The Netherlands, 1988.

73. Moreno, R.; Vayá, E. Técnicas Econométricas Para el Tratamiento de Datos Espaciales: La Econometría Especial; Edicions Universitat de Barcelona: Barcelona, Spain, 2000.

74. Stakhovych, S.; Bijmolt, T.H. Specification of spatial models: A simulation study on weights matrices. Pap. Reg. Sci. 2009, 88, 389-408. [CrossRef]

75. Getis, A.; Ord, J.K. The analysis of spatial association by use of distance statistics. Geogr. Anal. 1992, 24, 189-206. [CrossRef]

76. Silva, M.d.C.; Gavião, L.O.; Gomez, C.F.S.; Lima, G.B.A. A proposal for the application of multicriteria analysis to rank countries according to innovation using the indicators provided by the World Intelllectual Property Organization. RAI Rev. Adm. Innov. 2017, 14, 188-198. [CrossRef]

77. Kuc-Czarnecka, M.; Piano, S.L.; Saltelli, A. Quantitative Storytelling in the Making of a Composite Indicator. Soc. Indic. Res. 2020. [CrossRef]

78. Boix, R.; Capone, F.; De Propris, L.; Lazzeretti, L.; Sánchez, D. Comparing creative industries in Europe. Eur. Urban. Reg. Stud. 2016, 23, 935-940. [CrossRef]

79. Dominics, L.; Florax, R.J.; Groot, H.L. Regional clusters of innovative activity in Europe: Are social capital and geographical proximity key determinants? Appl. Econ. 2013, 45, 2325-2335. [CrossRef]

80. Boix, R.; Hervás-Oliver, J.L.; De Miguel-Molina, B. Micro-geographies of creative industries clusters in Europe: From hot spots to assemblages. Pap. Reg. Scie. 2015, 94, 753-772. [CrossRef]

81. Yu, V. Creative industries agglomeration and entrepreneurship in China: Necessity or opportunity? Ind. Innov. 2020, 27, 420-443. [CrossRef]

82. Rodrigues, M.; Franco, M. Taxonomy of Holistic Performance of Current Creative Cities: Empirical Study. J. Urban. Plan. Dev. 2020, 146. [CrossRef] 